UNIVERSIDADE DE BRASÍLIA - UNB

FACULDADE DE ECONOMIA, ADMINISTRAÇÃO, CONTABILIDADE E CIÊNCIA DA INFORMAÇÃO E DOCUMENTAÇÃ̃O

(FACE)

MARIA DE FÁTIMA JACOBINO

AVALIAÇÃO DE IMPACTO DO CURSO DE FORMAÇÃO E DESENVOLVIMENTO GERENCIAL 
Brasília-DF

2008

MARIA DE FÁTIMA JACOBINO

\section{AVALIAÇÃO DE IMPACTO DO CURSO DE FORMAÇÃO E DESENVOLVIMENTO GERENCIAL}

Monografia apresentada à Faculdade de Economia, Administração, Contabilidade e Ciência da Informação e Documentação (FACE), da Universidade de Brasília, como requisito parcial à obtenção do grau de Especialista em Gestão Universitária.

Orientadora: Prof ${ }^{a}$ Dra. Catarina Cecília Odelius

Brasília - DF

2008 
MARIA DE FÁTIMA JACOBINO

\title{
AVALIAÇÃO DE IMPACTO DO CURSO DE FORMAÇÃO E DESENVOLVIMENTO GERENCIAL
}

\author{
Profa. Dra. Catarina Cecília Odelius \\ Universidade de Brasília - Orientadora \\ Prof. Dra. Maria de Fátima Bruno Faria \\ Universidade de Brasília - Membro Titular
}

Brasília, 5 de junho de 2008 
"A sua capacidade necessita de responsabilidades para expor suas possibilidades. Faça o que você pode com o que você tem, onde você está."

Theodore Roosevelt 


\section{AGRADECIMENTOS}

A Deus que é poderoso para fazer infinitamente mais do que tudo quanto pedimos. A Ele toda honra e todo glória.

A meus pais (falecidos) em especial a minha mãe que sempre me estimulou a alcançar novos patamares na vida por meio do estudo.

A meus tios Ramiro e Idália minha segunda família.

A caminhada para chegar a este ponto foi suavizada por pessoas que compartilharam conhecimento e orientação, a eles eu agradeço e rogo as luzes do Espírito Santo: A Professora Doutora Catarina Cecília Odelius, minha orientadora, pela competência, atenção e dedicação.

Aos Professores do curso de Gestão Universitária, em especial a Professora Maria de Fátima Bruno Faria pela participação na banca examinadora e pelas contribuições ao trabalho.

As professoras Marisa Cardoso Trindade pelas valorosas informações sobre o curso de Formação e Desenvolvimento Gerencial; e a Professora Miramar Vargas pela atenção dispensada.

Ao Coordenador do curso Professor César Augusto Tibúrcio Silva e Secretária Vera Oliveira, exemplos de competência.

A Secretária de Recursos Humanos, ao Coordenador da Procap e colegas pelo apoio que facilitou a realização desta pesquisa.

Aos colegas do curso de Gestão Universitária.

Aos alunos da $4^{\mathrm{a}}$. Turma do curso de Formação e Desenvolvimento Gerencial que se dispuseram a participar desta pesquisa.

As valiosas contribuições dos amigos: Adélia Betty Ludovico de Almeida, Lindalva Lima Costa; Diolanda Moreira Veiga; Ana Lídia Gomes; Daniel Santos; Lia dos Anjos e Eulália dos Anjos; Hugo Rodrigues; Daniel; Regina Celly e Jorge.

A todos aqueles não citados mais que contribuíram para a realização desta pesquisa. 


\section{LISTA DE FIGURAS}

Figura 1 Ações de indução de aprendizagem em ambiente organizacionais .................17

Figura 2 Condições necessárias ao desempenho competente......................................22

\section{LISTA DE QUADROS}

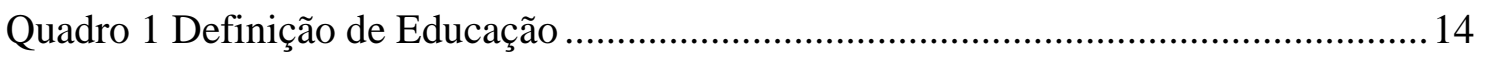

Quadro 2 Síntese dos principais conceitos relacionados a suporte .............................24

Quadro 3 Resumo dos conceitos de impacto no treinamento......................................2 


\section{LISTA DE TABELAS}

Tabela 1 Distribuição das pesquisas de acordo com o gênero e idade .33

Tabela 2 Distribuição das pesquisas de acordo com a escolaridade e formação.

Tabela 3 Distribuição dos pesquisados de acordo com o tempo de trabalho, subordinados, quantidade de subordinados, tipo de atividade e tempo na área 34

Tabela 4 Distribuição das respostas de acordo com a freqüência e importância de uso do conteúdo abordado na disciplina "Universidade Instituição". 35

Tabela 5 Distribuição das respostas de acordo com a freqüência e importância de uso do conteúdo abordado na disciplina "Os Sistemas da Universidade" 37

Tabela 6 Distribuição das respostas de acordo com a freqüência e importância de uso do conteúdo abordado na disciplina "Gestão da Universidade"

Tabela 7 Distribuição das respostas de acordo com a freqüência e importância de uso do conteúdo abordado na disciplina "Humanização da Universidade"..... 43

Tabela 8 Distribuição das respostas de acordo com a frequiência e importância de uso do conteúdo abordado na disciplina "Trabalho Final" 44

Tabela 9 Distribuição das respostas de acordo com a concordância o alcance dos objetivos 45

Tabela 10 Distribuição dos pesquisados de acordo com o gênero; idade; escolaridade e formação ..... .51

Tabela 11 Distribuição das pesquisados de acordo com o temo de trabalho, subordinados, quantos subordinados, tipo de atividade, outras atividades e atividades na área 52

Tabela 12 Distribuição dos pesquisados de acordo com a concordância para o alcance dos "objetivos" 


\section{RESUMO}

O objetivo da presente pesquisa foi identificar a freqüência e importância de uso dos conteúdos abordados no curso de Formação e Desenvolvimento Gerencial em situações de trabalho, de acordo com a percepção dos participantes do treinamento, de chefias e de pares. Foi feita análise dos conteúdos das disciplinas "Universidade Instituição"; "Os Sistemas da Universidade"; "Gestão da Universidade"; "Humanização da Universidade", "Trabalho Final" e preparado questionário para coleta de dados quanto a frequência e importância de uso dos conteúdos das disciplinas e à percepção de alcance dos objetivos do curso. Os questionários foram respondidos por 23 treinandos, 15 chefes e 17 pares. Os dados coletados na pesquisa de campo foram submetidos a análise estatística descritiva. Os resultados mostraram que , segundo a percepção dos pesquisados, o curso de Formação e Desenvolvimento Gerencial (FDG) atendeu aos seus objetivos.

Palavras-chave: Treinamento, desenvolvimento, avaliação de treinamento, impacto em profundidade, suporte à transferência, mudança de comportamento. 


\section{SUMÁRIO}

1 1 INTRODUÇÃ

1.1 Formulação do problema de pesquisa ........................................................ 10

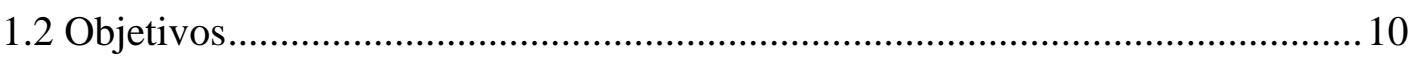

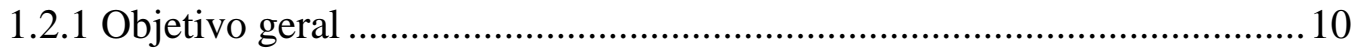

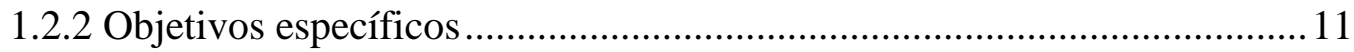

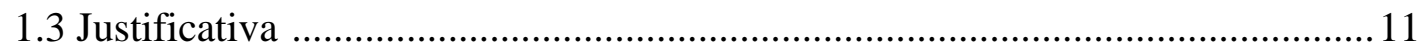

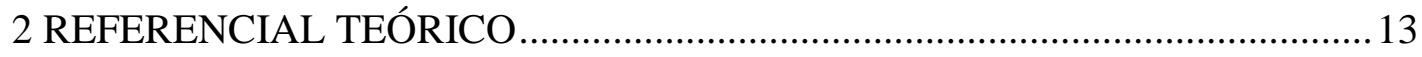

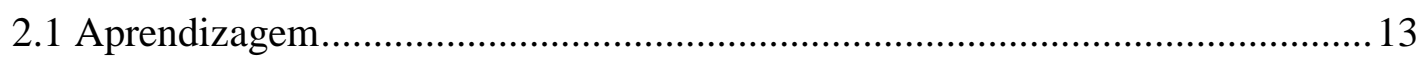

2.2 Conceituação de educação, treinamento e desenvolvimento.............................. 14

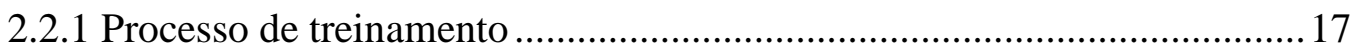

2.2.2 Modelos de avaliação de treinamento .....................................................2 21

2.3 Transferência de treinamento e impacto no......................................................23

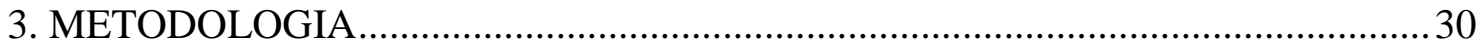

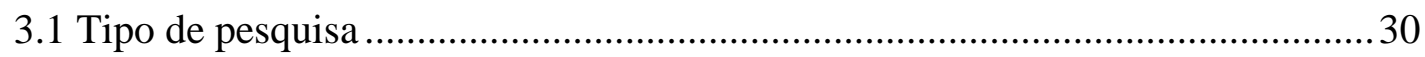

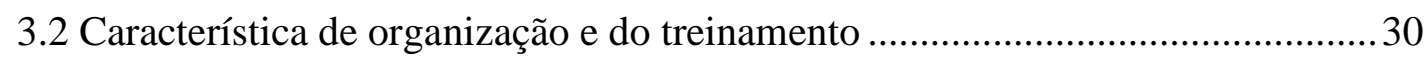

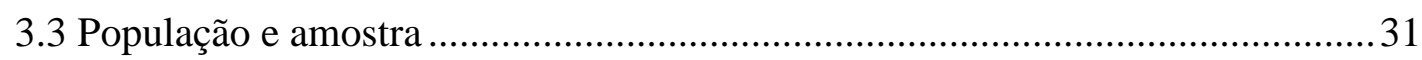





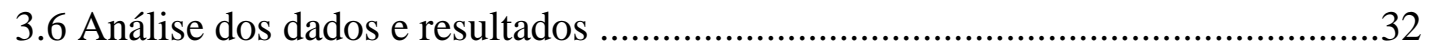

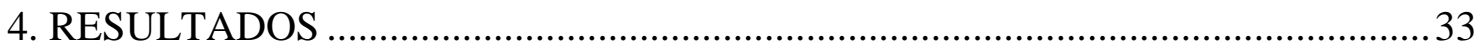

4.1 Resultados relativos à auto-avaliação ..................................................................33

4.2 Resultados da pesquisa relativos à hetero-avaliação .........................................51

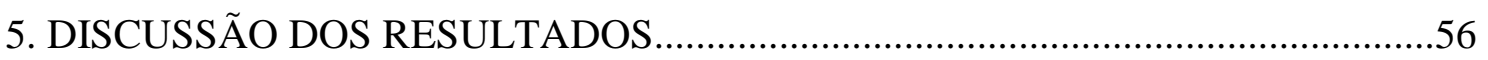

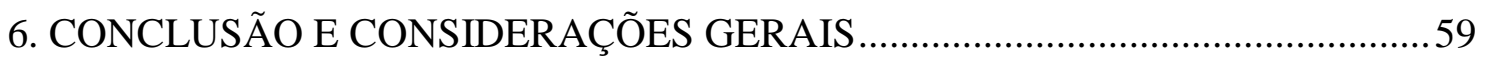

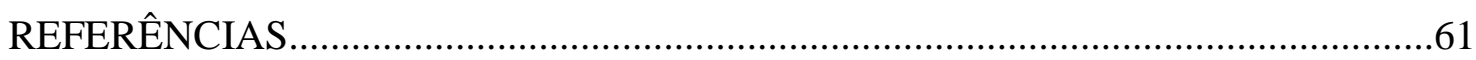

Apêndice - Convite via e-mail e questionário sobre avaliação de impacto do treinamento no trabalho 


\section{1 - INTRODUÇÃO}

É crescente a importância do treinamento nos dias atuais para as organizações, pesquisadores e empregados, por ser uma ferramenta capaz de preparar os empregados e consequentemente as organizações no sentido de enfrentar desafios presentes e futuros trazidos pela globalização, pelo desenvolvimento tecnológico, e pela mudança e transformação da sociedade (MENESES, 2007; ZERBINI; ABBAD, 2005).

$\mathrm{Na}$ busca por posturas dinâmicas diante das rápidas transformações e da alta competitividade do mundo do trabalho, as organizações têm aumentado consideravelmente seus investimentos em ações de Treinamento, Desenvolvimento e Educação (TD\&E) nos últimos anos. No entanto, as organizações têm questionado a eficácia das ações de treinamento tanto no retorno de seus investimentos, devido aos limitados e escassos recursos disponíveis para esse fim, quanto aos resultados de seus objetivos que são, entre outros, alcançar mudanças de atitudes e habilidades necessárias ao desempenho adequado de seus empregados (LACERDA; ABBAD, 2003, PEREIRA, 2007). Diante do aumento de investimentos em TD\&E, torna-se fundamental acompanhar a implementação de ações de capacitação e seus resultados.

Borges-Andrade (2000 p.1) ressalta essa tendência quando afirma que

existe crescente demanda por avaliação, nas organizações que tradicionalmente fizeram altos investimentos em treinamento, bem como naquelas que mais recentemente descobriram os valores estratégicos do conhecimento e do esforço na contínua qualificação do seu pessoal", e na visão de Drucker (1999, p.53) a administração deve definir os resultados que espera alcançar e depois organizar os recursos da organização visando a obtenção de resultados.

Atualmente, exige-se mais dos gerentes nas organizações, e é importante que estes estejam bem preparados e atentos para contextos mais complexos . Na concepção de Vargas (1996, p. 127)

(....) treinamento e desenvolvimento representa a aquisição sistemática de conhecimentos capazes de provocar, a curto ou longo prazo, uma mudança na maneira de ser e de pensar do indivíduo, por meio da internalização de novos conceitos, e valores ou normas e da aprendizagem de novas habilidades.

Imbuída de idéia semelhante, a Universidade de Brasília, nesses últimos anos, vem procurando capacitar de forma contínua os funcionários que fazem parte do seu quadro de pessoal à necessidade de conhecimentos prévios e teóricos, aplicando-os à prática diária, conforme a proposta de criação do curso de Formação e Desenvolvimento Gerencial implantado em agosto de 2005, visando atender prioritariamente os gerentes da UnB, 
portadores de diploma de nível médio, estendendo aos demais gerentes e ao público externo em geral.

O curso tem como objetivo possibilitar aos gerentes o desenvolvimento dos conhecimentos, habilidades e atitudes considerados relevantes para o desempenho de suas atividades e já foram concluídas quatro turmas.

Com o objetivo de levantar o impacto dessa ação de treinamento empreendida este trabalho se constituiu de uma parte introdutória na qual é contextualizado o problema e são explicados os objetivos de sua realização, em seguida fez-se uma justificativa na qual se aborda a importância e relevância do tema estudado, e conta ainda, com referencial teórico, que contém a revisão de conceitos de TD\&E, bem como trata da metodologia utilizada, da qual faz parte esse tipo de pesquisa, população e amostra, os instrumentos, procedimentos e a análise da coleta de dados e finaliza-se com as referências.

\subsection{Formulação do Problema de Pesquisa}

A Coordenadoria de Capacitação da Secretaria de Recursos Humanos da Universidade de Brasília implantou o Curso de Formação e Desenvolvimento Gerencial (FDG), em agosto de 2005, desde então concluíram o curso quatro turmas. No entanto até o momento não foi realizada avaliação de treinamento que pudesse identificar se houve mudanças de comportamentos, visão e atitudes as quais levassem a alcançar metas e objetivos propostos pela Instituição.

Qual(is) o(s) impactos do treinamento no trabalho do servidor para o desempenho de suas atividades?

\subsection{Objetivos}

\subsubsection{Objetivo geral}

Identificar o uso dos conteúdos abordados no curso de Formação e Desenvolvimento Gerencial em situações de trabalho, de acordo com a percepção dos participantes. 
1.2.2 Objetivos específicos

a) Descrever a importância das ações de Treinamento, Desenvolvimento e Educação (TD\&E) nas organizações.

b) Verificar a freqüência de uso e importância dos conteúdos abordados nas disciplinas "Universidade Instituição"; "Os sistemas da Universidade"; "Gestão da Universidade"; "Humanização da Universidade" e "Trabalho Final".

c) Identificar através de auto e heteroavaliações o alcance dos objetivos propostos no curso de Formação e Desenvolvimento Gerencial (FDG).

\subsection{Justificativa}

Essa avaliação de impacto de treinamento tem razão de ser tendo em vista que é de suma importância para o aprimoramento do curso de Formação e Desenvolvimento Gerencial (FDG), e visa desenvolver habilidades dos servidores que compartilham o seu trabalho com outras pessoas, assim como para o resultado dos esforços e investimentos financeiros empregados na capacitação de seus servidores, uma vez que até o momento não foram realizadas avaliações do treinamento mencionado.

Verifica-se na literatura consultada, entre as quais: Borges-Andrade (2002); Sallorenzo (2000) e Abbad (1999), que é preciso se avaliar treinamento continuamente para saber:

$>$ se houve aumento de produtividade; mudanças de comportamento e redução de custos;

$>$ se a eficácia em termos de impacto no trabalho e na organização como um todo de fato ocorreu de forma a justificar o investimento feito com o treinamento;

$>$ se alcançou os objetivos de ensino traçado no planejamento do curso;

$>$ e ainda se o treinando está usando o que aprendeu.

Se não é feita avaliação de resultados, há desperdício de investimento de recursos; distanciamento das necessidades estratégicas da empresa; excesso de teoria e exagero de investimento. E ainda que o aprendiz esteja satisfeito com o treinamento, isto não significa que o treinando esteja apto à execução de determinada tarefa e que irá aplicar no trabalho novas habilidades aprendidas.

A avaliação é o diferencial para saber se o treinamento foi lucrativo ou oneroso. Porém, resultados de pesquisa empírica vem mostrando que os cursos não têm sido capazes de 
produzir efeitos duradouros sobre o comportamento dos participantes e que no caso de transferência eficaz de conhecimentos, mudanças de nível de grupos e organizações não ocorrem necessariamente, tal como seguem as abordagens mais tradicionais de avaliação de eficácia de programas de treinamento.

Pretende-se com os resultados da pesquisa contribuir para estratégias relacionadas ao curso, de forma a realimentar o treinamento, bem como obter um melhor entendimento do impacto de treinamento na forma gerencial. 


\section{REFERENCIAL TEÓRICO}

Nesta parte descrevem-se os conceitos e abordagens relativas à aprendizagem, educação, treinamento, desenvolvimento e avaliação em TD\&E.

\subsection{Aprendizagem}

A busca pelo conhecimento e pelo aprendizado torna-se fator importante para indivíduos e organizações. Segundo Pereira (2007) Muitos autores afirmam que as organizações buscam promover a aprendizagem para promover inovações, atender às expectativas dos clientes e, assim, aumentar a competitividade e a atuação no mercado. Nesse sentido, López, Peón e Ordás (2005 apud PEREIRA, 2007) realizaram um estudo com o objetivo de verificar a relação entre a aprendizagem e o desempenho organizacional e obtiveram resultados que apontam a aprendizagem organizacional como variável preditora da performance das organizações estudadas. Para Vargas e Abbad (2006) o processo que envolve a aprendizagem humana no trabalho atraiu a atenção de estudiosos e pesquisadores que foram, gradativamente, tentando decifrar e caracterizar as diversas facetas do fenômeno.

Autores como Abbad e Borges-Andrade (2004), sob uma perspectiva psicológica, consideram que a aprendizagem é um processo que se realiza exclusivamente no nível dos indivíduos, sendo que seus efeitos podem se propagar pelos grupos, pelas equipes ou pela organização como um todo. Para esses autores os indivíduos aprendem em contextos sócioculturais, organizacionais e de experiência.

De acordo com Bitencourt (2004) a aprendizagem organizacional pode ser considerada uma resposta às mudanças enfrentadas pelas empresas em que se busca desenvolver a capacidade de aprender continuamente a partir das experiências organizacionais e a traduzir esses conhecimentos em práticas que contribuam para um melhor desempenho, tornando a empresa mais competitiva. Para tanto, a aprendizagem organizacional tem como pressuposto o desenvolvimento de estratégias e procedimentos a serem continuamente construídos para se atingirem melhores resultados, contando com a participação efetiva das pessoas no processo de aquisição e disseminação de conhecimento. Para essa autora tal condição se relaciona diretamente à questão do desenvolvimento de competências. 


\subsection{Conceituação de educação, treinamento e desenvolvimento}

$\mathrm{Na}$ visão de Abbad (1999) as diferenças entre educação, treinamento e desenvolvimento são na verdade, vantagens específicas que cada ação pode oferecer para a organização. Concordando com esta autora, distingue-se neste trabalho às diferenças entre educação, treinamento e desenvolvimento, busca-se, com isso, melhor compreensão destes conceitos, sua importância e complexidade.

Assim, educação é entendida como um processo pelo qual indivíduos adquirem domínio e compreensão de certos conteúdos considerados valiosos. Na visão de Odelius (2005) educação é toda influência que o ser humano recebe do ambiente social, durante toda sua vida, no sentido de adaptar-se ás normas, valores sociais vigentes e aceitos. Complementando, Nadler (1984 apud VARGAS; ABBAD, 2006) define o conceito de educação aplicado ao contexto das organizações de trabalho. Já Vargas e Abbad (2006) defendem a tese de que educação pode ser considerada uma das formas mais amplas de aprendizagem, com um escopo que extrapola o contexto específico do mundo do trabalho. Como mostram as definições:

\begin{tabular}{|c|c|}
\hline Dicionário Houaiss & Dicionário Webster \\
\hline $\begin{array}{l}\text { Educação } \\
\text { 1. Ato ou processo de educar(se). } \\
\text { qualquer estágio desse processo. } \\
\text { 2. aplicação dos métodos próprios para } \\
\text { assegurar a formação, o } \\
\text { desenvolvimento físico, intelectual e } \\
\text { moral de um ser humano, } \\
\text { conhecimento e desenvolvimento } \\
\text { resultantes desse processo. }\end{array}$ & $\begin{array}{l}\text { 1. Ação ou processo de educar ou ser } \\
\text { educado. Conhecimento e } \\
\text { desenvolvimento resultante de um } \\
\text { processo educacional. } \\
\text { 2. Campo de estudo que lida } \\
\text { principalmente com métodos de } \\
\text { ensino e aprendizagem nas escolas. }\end{array}$ \\
\hline
\end{tabular}

Quadro 1 - Definições de Educação

Fonte: Vargas e Abbad (2006, p.142)

Asseveram Vargas e Abbad (2006) que as definições de treinamento guardam grande coerência entre si. No entendimento de Borges-Andrade e Abbad (1996) uma das características primordiais do conceito de treinamento é a noção de que ele assume um esforço despendido pelas instituições para propiciar oportunidades de aprendizagem aos seus integrantes.

Na visão de Hinrichs (1976 apud VARGAS; ABBAD, 2006) treinamento pode ser definido como quaisquer procedimentos, de iniciativa organizacional, cujo objetivo é ampliar a aprendizagem entre os membros da organização. 
$\mathrm{Na}$ concepção de Goldstein (1991 apud VARGAS; ABBAD, 2006, p.140) "treinamento é uma aquisição sistemática de atitudes, conceitos, conhecimento, regras ou habilidades que resultem na melhoria do desempenho no trabalho".

No entendimento de Magalhães e Borges Andrade (2001), o treinamento pode ser visto como instrumento administrativo de vital importância para o aumento da produtividade do trabalho, e também como um fator de auto-satisfação do treinamento, construindo-se um agente motivador comprovado. Abrange uma somatória de atividades que vão desde a aquisição de habilidades motriz até o desenvolvimento de um conhecimento técnico complexo incluindo também a assimilação de novas atitudes, bem como modificações de comportamentos em função de problemas sociais amplos.

Num ambiente em constantes mudanças são muitas as exigências técnicas nas empresas para que se adeqüem ao mercado competitivo, pois encontram dificuldades para encontrar profissionais qualificados, desta forma busca-se a solução investindo em Treinamento, Desenvolvimento e Educação (TD\&E) de indivíduos. Para Spector (2006, p. 245)

\footnotetext{
o treinamento é uma das principais atividades na maioria das grandes organizações, incluindo as empresas do setor público (governo) e privado, em todo o mundo. Essa é uma atividade necessária tanto para funcionários novos como para os já experientes. Os novos funcionários devem aprender como realizar seu trabalho, enquanto os já experientes devem aprender a se manterem atualizados com as mudanças que ocorrem.
}

Segundo Borges-Andrade (1996) o treinamento visa identificar e superar deficiências no desempenho de empregados, preparando-os para novas funções e proporcionando retreinamento para adaptação da mão-de-obra à introdução de novas tecnologias no trabalho.

Assim sendo o treinamento vem sendo utilizado pelas empresas com o objetivo geral de desenvolver pessoas, tanto na aprendizagem de novas habilidades, quanto na ampliação daquelas já existentes, uma vez que as pressões sócio-culturais, tecnológicas, econômicas e políticas direcionam as organizações contemporâneas, a se adaptarem as exigências que o mercado impõe (CAMPOS et al., 2004).

De acordo com essas proposições, o treinamento se transforma num meio de suprir as carências dos indivíduos em termos de conhecimentos, habilidades e atitudes, para que possam desempenhar as tarefas necessárias ao alcance dos objetivos do indivíduo e da organização (GIL, 1994; SALAS; CANNON-BOWERS, 2001 apud CAMPUS et al., 2004).

De acordo com Bastos (1991) uma das maneiras de diferenciar treinamento dos demais é pelos critérios de intencionalidade em produzir melhorias de desempenho e do controle exercido pelas organizações sobre o processo de treinamento. 
Diferente de desenvolvimento e educação o conceito de treinamento estaria associado a intervenções sistematicamente planejadas para promoverem melhorias de desempenho em tarefas atuais. Já desenvolvimento estaria supostamente direcionado ao crescimento individual, e educação, voltada para atividades a serem realizadas em um futuro próximo.

Observa-se na literatura especializada que há duas correntes de pensamentos sobre os conceitos de desenvolvimento. Na primeira linha de raciocínio desenvolvimento engloba e não substitui o conceito de treinamento Bastos e Vargas (1996 apud VARGAS; ABBAD, 2006), para esses autores, treinamento, e desenvolvimento representam a aquisição sistemática de conhecimentos capazes de provocar, a curto e longo prazo uma mudança de ser e de pensar do indivíduo, por meio da internacionalização de novos conceitos, valores ou normas e da aprendizagem de novas habilidades.

Enquanto na segunda linha de raciocínio faz-se distinção entre treinamento e desenvolvimento, sem a mesma amplitude. Define-se, portanto, desenvolvimento como voltado para o crescimento pessoal do indivíduo, não necessariamente visando à melhoria de desempenho (BORGES-ANDRADE et al., 2000) e ou ainda: refere-se às ações voltadas para a carreira do indivíduo.

DeCenzo e Robbins (2001 apud CARVALHO, 2004), com muita propriedade, diferenciam treinamento de empregados de desenvolvimento de empregados, defendendo a idéia de que embora "ambos sejam similares nos métodos usados para transmitir a aprendizagem, as estruturas do tempo variam". Esses autores conceituam que "o treinamento é mais orientado para o presente, seu foco são as habilidades e capacidades específicas para desenvolvimento". Percebe-se as similaridades na conceituação dos termos mais a diferença auxilia no desempenho das atividades necessárias ao cargo que será ocupado em organizações dinâmicas.

Afirmam Silva e Moraes (2004) que um programa de desenvolvimento gerencial pode ser interpretado como treinamento de potencialização e possibilita contribuir para o desenvolvimento das características pessoais dos treinandos. Acrescenta ainda que o desenvolvimento de gerentes, tendo como intenção a transferência de informações, também abrange o desenvolvimento de conhecimentos, habilidades e atitudes, o que determina um conjunto de competências gerenciais. Uma vez que o corpo gerencial é primordial para a consecução dos objetivos organizacionais, sua ação pressupõe o conhecimento e compreensão de todo o mecanismo de desenvolvimento da instituição. 
Mostra a Figura 1, depois das várias concepções apresentadas, que educação assume uma complexidade maior englobando o conceito de desenvolvimento, e que treinamento tem uma proposta comum que é a habilidade e atitude requeridas para o desempenho do trabalho.

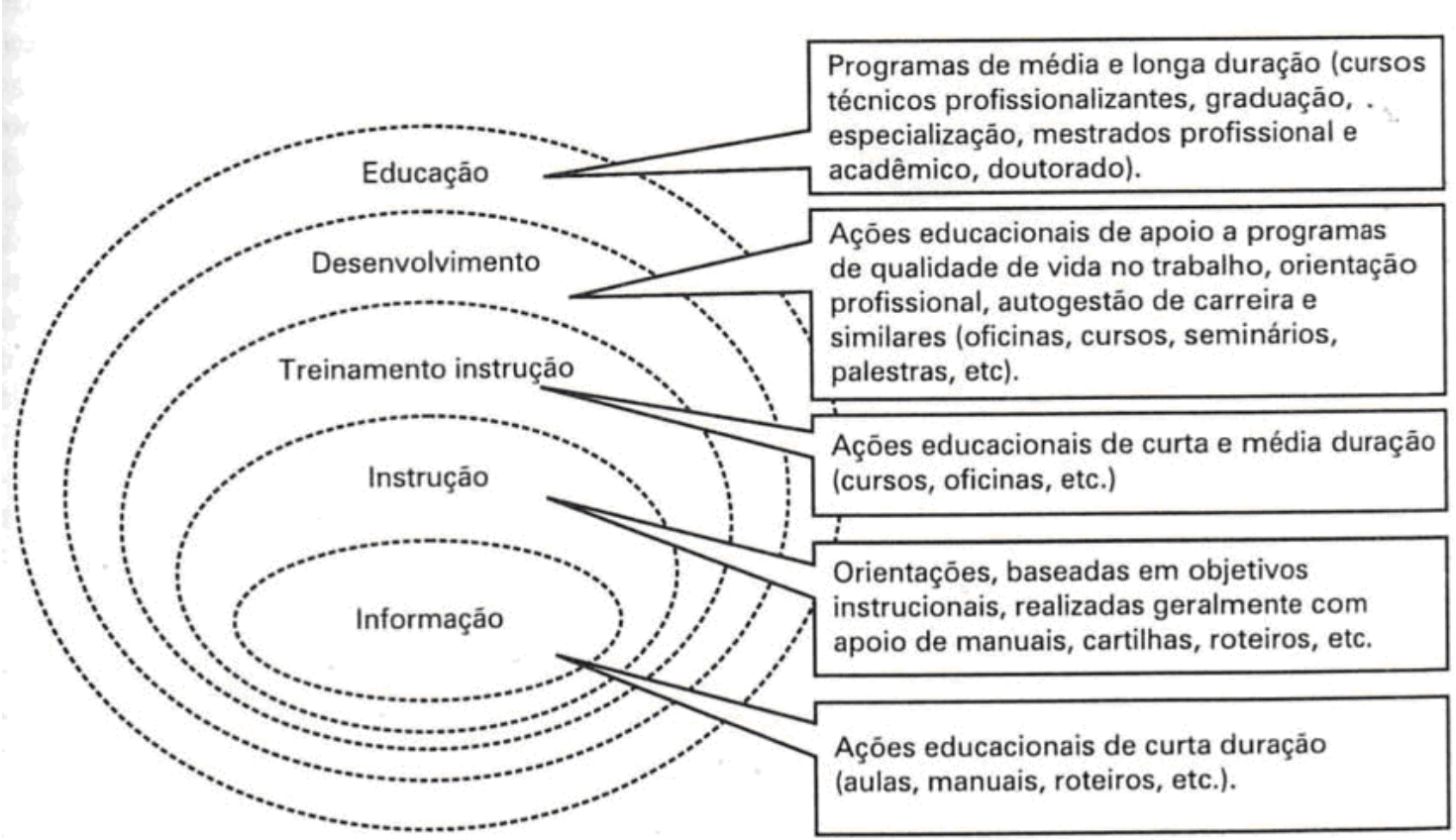

Figura 1 - Ações de Indução de aprendizagem em ambiente organizacionais Fonte: Vargas e Abbad (2006, p. 143).

\subsubsection{Processo de treinamento}

Entende Rosemberg (2001 apud VARGAS; ABBAD, 2006) que o papel do treinamento é apoiar os indivíduos na aquisição de uma nova habilidade, utilizar um novo conhecimento de uma determinada maneira ou em um determinado nível de proficiência e, algumas vezes, dentro de um específico período de tempo. Já a concepção de Boog (1999) a abrangência do papel do treinamento na empresa de hoje, não se restringe apenas em oferecer condições para que os empregados melhor se capacitem ou se desenvolvam, mas também e principalmente, como força capaz de intervir na organização e no processo produtivo.

Em termos de treinamento, o paradigma sistêmico tem sido o referencial teórico predominante na literatura científica, tanto no Brasil quanto no exterior (BORGESANDRADE; ABBAD, 1996). Observa-se, a seguir, na definição de Rosemberg (2001) que houve um detalhamento de cada subsistema de treinamento como forma de ampliar a base do conhecimento. A mesma tendência não pode ser observada na definição de Borges-Andrade 
(2006), no entanto em ambas há uma mesma estruturação e conteúdo, diferenciando-se apenas, na divisão do sistema planejamento e execução.

O treinamento, na visão de Rosemberg (2001 apud VARGAS; ABBAD, 2006) apresentam quatro elementos principais:

$>$ intenção de melhorar um desempenho específico, normalmente derivada de uma avaliação de necessidade e refletida na elaboração de objetivos instrucionais.

$>$ o desenho que reflete a estratégia instrucional que melhor se ajusta à aprendizagem requerida e ás características da clientela, bem como às estratégias de mensuração que apontam a eficácia do treinamento.

os meios pelos quais à instrução é entregue, que pode incluir a sala de aula, uma variedade de tecnologias, estudos independentes ou a combinação de diferentes abordagens.

avaliação, cujos níveis de complexidade podem variar desde situações mais simples até as mais formais que incluem exigências de certificação.

Já para Borges-Andrade (2006, p. 343) o treinamento, o desenvolvimento e a educação podem ser visto pelas organizações como um sistema integrado por três subsistemas: a) avaliação de necessidade; b) planejamento e execução e c) avaliação de TD\&E.

a) - Avaliação de necessidade de treinamento

Magalhães e Borges-Andrade (2001) afirmam que é a partir da avaliação de necessidade que a organização estabelece suas prioridades. Para Borges-Andrade (2006) é por meio da avaliação que são apontadas as deficiências de desempenho a serem corrigidas por meio de ações de treinamento e fornecidas as informações necessárias ao planejamento instrucional e à avaliação.

Na perspectiva de avaliação de necessidade de treinamento, as tendências atuais são de desenvolvimento de métodos cada vez mais apropriados para a identificação de necessidades emergentes de capacitação. Esses métodos buscam alinhar as ações de treinamento às estratégias organizacionais. Assim, o uso de técnicas de levantamento de necessidades futuras ou "virtuais" é uma ferramenta muito importante para o planejamento da instrução alinhado com as competências individuais que terão de ser desenvolvidas para a organização atingir seus objetivos (PILATI, 2006).

Basicamente, o treinamento se efetua de acordo com cinco etapas necessárias para que os programas de treinamento das organizações sejam eficazes: a primeira etapa de um 
programa de treinamento é conduzir um estudo da avaliação das necessidades, de forma que determine quem precisa, e que tipo de treinamento; a segunda etapa é definir os objetivos do treinamento; a terceira é projetar o programa de treinamento; a quarta é aplicar o treinamento aos funcionários definido pela avaliação de necessidades; a última etapa é avaliar o programa de treinamento para se certificar de que ele atingiu seus objetivos. Cada etapa deve ter como base a que a precede (SPECTOR, 2006).

$\mathrm{Na}$ concepção de Abbad et al., (2006) a necessidade de treinamento pode ser de diferentes níveis: organização, tarefas/grupos, equipes, células de trabalho, redes e individuais. Para Goldstein (1991, apud ABBAD, 1999) os treinamentos deveriam ser previstos nas organizações após a identificação das necessidades diagnosticadas em três níveis: analise organizacional (investigação se o treinamento é realmente necessário e se existe suporte para transferência das habilidades adquiridas), análise de tarefas (identificação dos conhecimentos, habilidades e atitudes, e análise pessoal - análise do desempenho).

Afirmam Abbad, Freitas e Pilati (2006): para se avaliar necessidades individuais de treinamento, desenvolvimento e educação, podem-se definir necessidades como (Gaps) hiatos de competências, descritos em termos de conhecimentos, habilidades e atitudes (CHAs). Além disso, é preciso avaliar a magnitude do hiato, bem como quais são as conseqüências para a organização, se ignora-la.

Segundo Spector (2006) apesar da importância da avaliação de necessidade de treinamento, as organizações frequentemente não a utilizam. E ou, de acordo com Nogueira Júnior (2003) o fator apontado como o principal responsável pelo insucesso de muitos programas de treinamento é representado pela inadequação dos procedimentos utilizados.

b) O planejamento e execução

De acordo com Abbad et al., (2006), o planejamento é a criação ou escala de situações que induzem à aprendizagem de conhecimentos, habilidades e atitudes (CHAs). Essas situações são chamadas de estratégias, métodos, técnicas, procedimentos, recursos e meios instrucionais. Na concepção dessa autora para que o planejamento instrucional possa ocorrer a contento é preciso transformar as descrições de necessidades de treinamento em objetivos instrucionais.

No entendimento de Mager (1976 apud ABBAD et al., 2006) objetivos bem descritos facilitam a escolha de meios e estratégias de ensino, bem como a avaliação. O objetivo deve comunicar seu propósito, ou seja, deve explicitar o que exatamente o aprendiz será capaz de 
dizer ou fazer, após a instrução. Complementa Tannembaum e Yukl (1992, apud SILVA, 2002) que é no planejamento que são definidos os objetivos instrucionais, o conteúdo programático e as estratégias de ensino e identificadas às características de clientela, bem como feitas as considerações práticas, tais como a avaliação do custo-benefício do treinamento para a organização.

De acordo com Abbad (1999) questões empíricas que envolvem o planejamento de treinamento têm se voltado para aspectos psicológicos da clientela que afetam a aprendizagem e a transferência de conhecimentos, habilidades e atitudes adquiridas.

c) Avaliação de TD\&E

Na concepção de Hamblin (1978) avaliação é o ato de julgar se o treinamento valeu a pena ou não em termos de algum critério de valor à luz da informação disponível. Para esse autor a avaliação é tratada como uma característica integral do sistema sendo um meio para aperfeiçoá-lo, não é um fim em si mesma. Nas palavras de Abbad (1999, p. 8) “Avaliação de treinamento é um conjunto de atividades, princípios, prescrições teóricas e metodológicas que visa, entre outros objetivos, produzir informações válidas e sistemáticas sobre eficácia de sistemas instrucionais".

O subsistema avaliação de treinamento assume um papel decisivo na medida em que se constitui de um conjunto de atividades através dos quais são coletados, organizados e interpretados dados acerca do funcionamento do sistema de treinamento visando ao seu contínuo aperfeiçoamento (PANTOJA, 1999).

De modo geral as organizações carecem de estudos criteriosos que busquem investigar o retorno de seus investimentos em termos de transferência de aprendizagem, mudança de comportamento ou impacto de treinamento. Segundo Meneses (2002); Zerbini (2003) e Freitas (2005) crescem os questionamentos sobre a eficácia dos programas de treinamento e o retorno desses investimentos, assim também, crescem os esforços para avaliar programas de TD\&E, com o objetivo de produzir conhecimentos válidos e sistemáticos sobre a efetividade de sistemas instrucionais e produzir conhecimentos científicos sobre os fenômenos relacionados à aprendizagem e à transferência de novas aprendizagens para o trabalho.

No entendimento de Pereira (2007) em função do aumento de investimentos em TD\&E, torna-se fundamental acompanhar a implementação de ações de capacitação e os resultados. A pesquisa em avaliação de TD\&E permite ao pesquisador e ao profissional da área, por exemplo, verificar se houve retorno dos investimentos feitos com treinamento para a 
organização. Essas informações são consideradas imprescindíveis para a definição de políticas de distribuição de recursos para a área de TD\&E, para que essa área mantenha o posicionamento estratégico nas organizações e o status de ciência obtido.

No entendimento de Zerbini (2003); Pantoja, 1999; Borges-Andrade e Abbad (1996) a avaliação de treinamento é um elemento essencial, pois é responsável pelo fornecimento constante de sistema de treinamento. Para Zerbini (2003) é muito difícil analisar as mudanças de desempenho, motivação e comprometimento dos funcionários após os treinamentos, sem metodologia sistemática e avaliação dos resultados. Defende Meneses (2002), "a etapa de avaliação de treinamento compreende a coleta sistemática de informações descritivas e de julgamento a fim de tornar efetiva valoração e modificação das varias atividades instrucionais".

Marra (2000, p.159) afirma que a finalidade da etapa de avaliação de treinamento é de "aferir os resultados conseguidos comparativamente àquilo que foi planejado e esperado pela organização". Para Kanaane e Ortigoso (2001, p.144), "a busca de resultados está associada aos fatores extraídos do ambiente de trabalho e que servem de parâmetros para o alcance de produtividade e qualidade, aliados ao retorno dos investimentos efetuados".

A avaliação de treinamento deve considerar dois aspectos principais: - determinar até que ponto o treinamento realmente produziu as modificações desejadas no comportamento dos empregados; e - verificar se os resultados do treinamento apresentam relação com a consecução das metas da empresa (CHIAVENATTO, 1999)

De acordo com Odelius (1999), a avaliação do treinamento pode oferecer diversos benefícios, entre os quais: o auxilio na adequação do treinamento com o plano estratégico da organização; o apoio no rastreamento daqueles que foram treinados e daqueles que necessitam de treinamentos; a identificação das barreiras que confrontam as equipes e dificultam o progresso; o estabelecimento de critérios para reconhecimento e recompensa dos participantes e geração de que vise à melhoria continuada do programa.

2.2.2 Modelos de avaliação de treinamento

A seguir alguns dos principais modelos de avaliação de treinamento que foram desenvolvidos por pesquisadores em função de sua relevância para esta pesquisa. Afirma Vargas (1996): por melhor e mais bem elaborado que seja um programa de treinamento, a escolha de um método inadequado ou ineficiente poderá colocar em risco todo o processo.

A partir da análise da literatura nacional e estrangeira sobre Avaliação de TD\&E, 
verificam-se crescentes avanços na área. Pesquisadores no Brasil e no Exterior, preocupados com tais questões, constroem modelos de avaliação de treinamento e fornecem resultados que constituem respaldo técnico-científico aos profissionais da área (SALORENZO, 2000).

Para Meneses (2006) medir resultados de programas de treinamento consiste na elaboração de modelo capaz de contemplar todas as possibilidades de efeitos de uma ação educacional sobre o desempenho organizacional. Para essa autora, a escolha das medidas mais adequadas de efetividade organizacional dependeria de quem são os constituintes e quais seus principais interesses nas atividades da organização.

Entre os modelos consagrados pela literatura científica destacam-se os modelos de Kirkpatrick (1976) e Hamblin (1978). Ambos propuseram que avaliação de treinamento deveria seguir alguns níveis.

Hamblin (1978) sugere cinco níveis, sendo que os dois últimos são desdobramentos do quarto nível proposto por Kirkpatrick (1976):

a) Reação, que levanta atitudes e opiniões dos treinandos sobre os diversos aspectos do treinamento, ou sua satisfação com o mesmo.

b) Aprendizagem, que verifica se ocorreu diferenças entre o que os treinandos sabiam antes e depois do treinamento, ou se os objetivos instrucionais do treinamento foram alcançados.

c) Comportamento no cargo, que leva em conta o desempenho dos indivíduos antes e depois do treinamento, ou se houve transferência deste treinamento para o trabalho efetivamente realizado.

d) Organização, que toma como critério de avaliação o funcionamento da organização, ou mudanças que nela possam ter ocorrido em decorrência do treinamento.

e) Valor final, que tem como foco a produção, o serviço prestado ou o alcance dos objetivos globais da organização, o que geralmente acaba implicando em comparar custos do treinamento com os seus benefícios monetários ou com o lucro obtido por causa de sua realização.

Outros modelos se sobressaem na área de avaliação de TD\&E:

De acordo com Borges-Andrade (1982) o Modelo de Avaliação Integrado e Somativo (MAIS) está estruturado em cinco componentes, quais sejam: 1) Insumo - compreende, em sua maior parte, características dos treinandos presente antes do início do treinamento (ex. aspectos motivacionais, demográficos). 2) Procedimentos - são variáveis instrucionais, ou “operações necessárias para facilitar ou produzir os resultados instrucionais”, como por exemplo, sequiência de objetivos, meios estratégicos instrucionais, exercícios propostos. 3) 
Processo - refere-se aos resultados intermediários ou efeitos parciais do treinamento ocorridos no comportamento dos treinandos à medida que os procedimentos são apresentados durante o treinamento. 4) Resultados - são os efeitos imediatos produzidos pelo treinamento, ou seja, são os desempenhos dos treinandos adquiridos logo após os treinamentos. 5) Aspectos do ambiente - (subdividindo-se em: avaliação de necessidade, disseminação, apoio e resultados à longo prazo).

Ao avaliar todos os componentes do modelo MAIS, inclusive as variáveis do ambiente, os resultados da avaliação serão precisos e úteis para propor as mudanças no sistema de treinamento. Todos esses elementos visam formar variáveis que passou a ser estruturados e a oferecer referências que auxiliaram na identificação de princípios a serem testados na organização. Este modelo propõe uma avaliação sistemática de sistemas instrucionais com o intuito de promover oportunidade de construção de conhecimento, integrando planejamento, obtenção e análise de informações (BORGES-ANDRADE, 2006). Já o modelo de Avaliação do Impacto do Treinamento no Trabalho - IMPACT concebido por Abbad (1999), é composto por sete componentes: percepção de suporte organizacional, características de treinamento, características da clientela, reação, aprendizagem, suporte à transferência e impacto de treinamento no trabalho. Os seis primeiros componentes do modelo de avaliação abrangem as variáveis preditoras do impacto do treinamento no trabalho.

\subsection{Transferência de treinamento e impacto no trabalho}

É muito importante conhecer os conceitos de transferência de treinamento e impacto de trabalho, pois quando se fala da aplicação correta, no trabalho, de conhecimentos, habilidades e atitudes adquiridas durante um evento de treinamento, está se referindo a "transferência de treinamento". Ao mencionar-se aquilo que o indivíduo transfere ou aplica ao ambiente de trabalho, trata-se de uma nova forma de realizar antigas tarefas de um novo desempenho (ABBAD, 1999). Isso ocorre segundo Facteau (1995 apud SPECTOR, 2006), em um ambiente que dê apoio, no qual os supervisores e outras pessoas encorajam a aplicação dos princípios aprendidos, o que resulta na motivação dos funcionários a aprender e a transferir o que foi aprendido no treinamento.

A menos que haja apoio dos funcionários e de seus supervisores, nem mesmo o melhor treinamento resultará nos efeitos desejados. Conseguir o apoio é uma tarefa complexa que vai além de projetar adequadamente um treinamento. O treinamento nas organizações acontece no contexto de um ambiente de trabalho complexo. A utilização ou não no trabalho 
daquilo que foi aprendido no treinamento depende em larga medida do ambiente de trabalho (SPECTOR, 2006).

No entendimento de Borges-Andrade (2004) na avaliação de transferência é importante considerar se os efeitos almejados são esperados no desempenho do aprendiz, da organização ou em termos dos lucros. Estes três níveis distintos requerem tipos diferenciados de mensuração. No caso de transferência para o desempenho do aprendiz no trabalho, os efeitos podem ser verificados em "profundidade" (conceito no Quadro 3) e em "amplitude" ou "largura". Os efeitos em "amplitude" são verificados com base em todos os desempenhos esperados do aprendiz, e não somente naqueles diretamente relacionados aos CHAs esperados. Em ambas situações, buscar-se-ão evidências da aplicação das competências no trabalho, usando observações e registros ou perguntando ao aprendiz e a seus superiores, colegas e clientes.

Os conceitos apresentados no Quadro 2 referem-se a fatores do contexto interno à organização e o avaliam de acordo com a perspectiva de variáveis que antecedem ou sucedem o desempenho avaliado. Eles diferem entre si no que diz respeito ao foco e às demais perspectivas de análise.

\begin{tabular}{|c|c|c|}
\hline Conceito & Definição & Autor(res) \\
\hline $\begin{array}{l}\text { Suporte } \\
\text { organizacional }\end{array}$ & $\begin{array}{l}\text { Percepção dos indivíduos a respeito do quanto a organização se } \\
\text { preocupa com o bem-estar e valoriza as contribuições dos indivíduos } \\
\text { que nela trabalham }\end{array}$ & $\begin{array}{l}\text { Abbad (1999); Abbad, } \\
\text { Pilati e Borges- } \\
\text { Andrade (1999) }\end{array}$ \\
\hline $\begin{array}{l}\text { Suporte gerencial } \\
\text { ao treinamento }\end{array}$ & $\begin{array}{l}\text { Indicadores de apoio gerencial à transferência de treinamento, } \\
\text { presentes no ambiente organizacional antes, durante e após o } \\
\text { treinamento. }\end{array}$ & 1982) \\
\hline $\begin{array}{l}\text { Clima para } \\
\text { transferência }\end{array}$ & $\begin{array}{l}\text { Percepção do indivíduo sobre o apoio que recebe do ambiente } \\
\text { organizacional para transferir novas aprendizagens para o trabalho. } \\
\text { Este conceito inclui fatores situacionais antecedentes e } \\
\text { conseqüências associadas à transferência de treinamento. }\end{array}$ & $\begin{array}{l}\text { Rouiller e Goldstein } \\
\text { (1993) }\end{array}$ \\
\hline $\begin{array}{l}\text { Suporte } \\
\text { transferência }\end{array}$ & $\begin{array}{l}\text { Percepção do indivíduo sobre o apoio que recebe de colegas e } \\
\text { chefias para aplicar, no trabalho, novas habilidades adquiridas em } \\
\text { treinamentos. Além do suporte psicossocial, esse conceito enfoca o } \\
\text { apoio material à transferência de treinamento. }\end{array}$ & $\begin{array}{l}\text { Abbad (1999); Abbad } \\
\text { e Sallorenzo (2001) }\end{array}$ \\
\hline $\begin{array}{l}\text { Suporte } \\
\text { aprendizagem }\end{array}$ & $\begin{array}{l}\text { Percepção do indivíduo sobre o apoio de pares e chefias á } \\
\text { aprendizagem e á aplicação no trabalho de CHAs adquiridos em } \\
\text { situações em situações formais (programas de TD\&E) e informais de } \\
\text { aprendizagem. }\end{array}$ & Coelho Jr. (2004) \\
\hline $\begin{array}{l}\text { Suporte } \\
\text { Psicossocial }\end{array}$ & $\begin{array}{l}\text { Representa a relação interpessoal de apoio oferecida pelos chefes e } \\
\text { colegas para aplicação do aprendido. }\end{array}$ & Freitas $(2005$, p. 39$)$ \\
\hline
\end{tabular}

Quadro 2 - Síntese dos principais conceitos relacionados a suporte.

Fonte: Abbad et al. (2006, p. 397) 
Verifica-se, no Quadro 2, que há vários conceitos relativos ao ambiente. Alguns desses são muito similares entre si, apesar de terem sido originados em contextos e abordagens teóricas distintos.

Abbad (1999) sugere que para medir os resultados de um treinamento, deve-se avaliar o desempenho, a motivação e as atitudes da clientela depois do término do treinamento. Para essa autora deve-se observar o desempenho do indivíduo no trabalho, ou seja, a aplicação do aprendido no ambiente de transferência, é preciso mais do que saber (habilidades). O indivíduo também precisa querer fazer a tarefa (motivação) e ter condições no ambiente para fazê-lo.

O conceito de desempenho no trabalho é usado para exprimir um conjunto de comportamentos ligados a tarefas, papéis, normas, expectativas, metas e padrões de eficiência e eficácia estabelecidas em ambientes organizacionais. $\mathrm{O}$ desempenho inclui o que, como, onde, quando, para que e com que padrões as tarefas são executadas pelas pessoas (ABBAD e colaboradores, 2004).

Abbad, Freitas e Pilati (2006, p. 238) citam que são necessárias certas condições para que o indivíduo obtenha um desempenho eficaz. É preciso saber fazer e querer fazer a tarefa de acordo com certo padrão. Faz-se necessário ainda um suporte organizacional para execução eficaz da tarefa. As idéias desses autores são demonstradas na Figura 2.

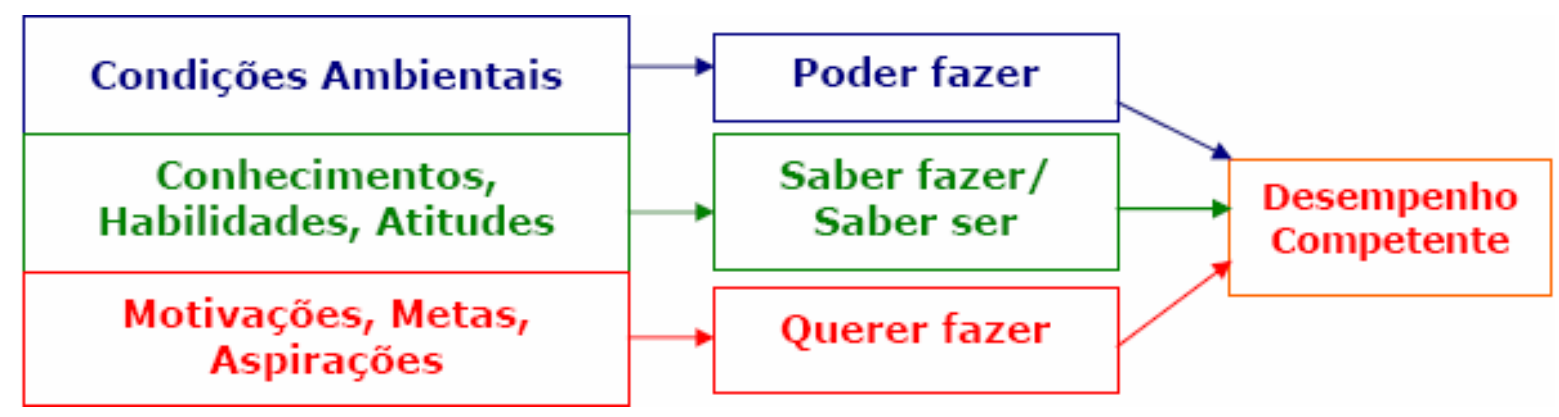

Figura 2 condições necessárias ao desempenho competente.

Fonte: Abbad e Borges-Andrade (2004).

Pilati e Abbad (2005) fazem uma proposição conceitual de uma cadeia de eventos que levaria uma ação de TD\&E a surtir efeitos no desempenho de participantes de ações educacionais: a) seria iniciado pelo processo de aquisição de competências, resultado imediato da ação instrucional. b) essa aquisição permitiria o processo de retenção de conhecimentos e habilidades, diretamente relacionada à generalização dos comportamentos, resultantes das novas competências, em situações diferentes daquelas tratadas no evento de TD\&E; e por fim, a generalização e seus efeitos sobre a atuação do indivíduo. 
Para Sallorenzo (2000), quanto maior o intervalo entre o término de uma ação educacional e a observação dos efeitos desejados, tanto maior será o número de variáveis que poderão interferir nas relações entre programas de TD\&E e seus efeitos no desempenho de uma organização, essas interferências caso não previstas e contornadas, ou pelo desempenho na implementação do programa ou pelo emprego de procedimentos de análise de dados, podem representar grandes limitações ao estabelecimento de relações válidas e confiáveis.

Suporte favorável ao desempenho, à aprendizagem e a transferência de treinamento, por outro lado, está relacionado à melhores resultados de ações de TD\&E, de modo que surtem maiores efeitos os treinamentos realizados em organizações e ambientes de trabalho apoiadores da aprendizagem e de sua aplicação (ABBAD; FREITAS; PILATI, 2006).

Entende Abbad (1999) que impacto do treinamento no trabalho compreende os conceitos de transferência de treinamento e desempenho no trabalho. Para a autora o impacto do treinamento no trabalho é auferido a partir da transferência de treinamento ocorrida e sua influência sobre o desempenho subseqüente do participante do treinamento. Na concepção dessa autora é importante ressaltar que o impacto está sempre relacionado ao desempenho pós-realização do treinamento. No entanto nem sempre às organizações nas ações educacionais, fazem diagnósticos ou prognósticos de necessidades na especificação de resultados de treinamento de um programa de treinamento. 
O Quadro3 resume conceitos de impacto no treinamento e aspectos que os autores recomendam e/ou indicam estar associados ao impacto no treinamento.

\begin{tabular}{|c|c|c|}
\hline Autor(res) & Definição de Impacto no treinamento & Aspectos \\
\hline $\begin{array}{l}\text { Freitas et al., } \\
(2006)\end{array}$ & $\begin{array}{l}\text { A ocorrência de melhorias significativas no } \\
\text { desempenho específico ou no desempenho geral da } \\
\text { aplicação no trabalho, CHAs aprendido em TD\&E. }\end{array}$ & $\begin{array}{l}\text { Melhorias significativas; } \\
\text { desempenho específico; } \\
\text { desempenho geral. }\end{array}$ \\
\hline $\begin{array}{l}\text { Pilati e Abbad } \\
(2005)\end{array}$ & $\begin{array}{l}\text { é a influência que o evento instrucional exerce sobre o } \\
\text { desempenho global subseqüente do participante do } \\
\text { treinamento bem como em suas atitudes e motivação. }\end{array}$ & $\begin{array}{l}\text { Influência; desempenho global; } \\
\text { atitudes, motivação. }\end{array}$ \\
\hline $\begin{array}{l}\text { Borges-Andrade } \\
(2004)\end{array}$ & $\begin{array}{l}\text { mede os efeitos do treinamento que estão relacionados } \\
\text { aos conteúdos ensinados e programas de treinamentos. } \\
\text { Busca avaliar habilidades, conhecimentos e atitudes. }\end{array}$ & $\begin{array}{l}\text { efeitos do treinamento; } \\
\text { avaliar habilidades e atitudes. }\end{array}$ \\
\hline Zerbini (2003) & $\begin{array}{l}\text { é o principal indicador de efetividade de ações de } \\
\text { treinamento no nível de avaliação de treinamento, } \\
\text { impacto é um indicador de mudança do comportamento } \\
\text { no cargo. } \\
\text { - efeitos específicos do treinamento sobre o } \\
\text { desempenho do participante em atividades diretamente } \\
\text { relacionados aos CHAs desenvolvidos no treinamento. }\end{array}$ & $\begin{array}{l}\text { Indicador de efetividade } \text { de } \\
\text { ações; } \\
\text { indicador de mudanças do } \\
\text { comportamento. }\end{array}$ \\
\hline $\begin{array}{l}\text { Abbad, Pantoja } \\
\text { e Pilati (2001) }\end{array}$ & $\begin{array}{l}\text { é o efeito de longo prazo exercido pelo treinamento nos } \\
\text { níveis de desempenho e motivação do participante. }\end{array}$ & $\begin{array}{l}\text { efeito de longo prazo; } \\
\text { desempenho, motivação. }\end{array}$ \\
\hline Abbad (1999) & $\begin{array}{l}\text { Auto-avaliação (feita pelo próprio participante) e } \\
\text { hetero-avaliação (feita pelos supervisores, pares e } \\
\text { cliente) acerca dos efeitos produzidos pelo treinamento } \\
\text { em seus níveis de desempenho, motivação, auto } \\
\text { confiança e abertura a mudanças nos processos de } \\
\text { trabalho. } \\
\text { - efeitos do treinamento sobre desempenho da pessoa } \\
\text { no trabalho, durante a execução de tarefas similares de } \\
\text { avaliação de comportamento, proposto por Kirkpatrick } \\
\text { (1976) e Hamblin (1978). }\end{array}$ & $\begin{array}{l}\text { auto-avaliação, e hetero- } \\
\text { avaliação; } \\
\text { efeitos produzidos; desempenho, } \\
\text { motivação, autoconfiança; } \\
\text { abertura a mudança. }\end{array}$ \\
\hline Hamblin (1978) & $\begin{array}{l}\text { distingue efeitos específicos de um evento instrucional } \\
\text { de outros, mais gerais e não extraídos diretamente dos } \\
\text { objetivos de ensino. }\end{array}$ & $\begin{array}{l}\text { efeitos específicos de evento } \\
\text { instrucional. }\end{array}$ \\
\hline $\begin{array}{l}\text { Kirkpatrick e } \\
\text { Philips (1976) }\end{array}$ & $\begin{array}{l}\text { mede a transferência para o trabalho das habilidades } \\
\text { adquiridas no treinamento. ( } 3^{\mathrm{a}} \text {. nível de avaliação). }\end{array}$ & $\begin{array}{l}\text { transferência para o trabalho das } \\
\text { habilidades. }\end{array}$ \\
\hline
\end{tabular}

Quadro 3 - Conceitos de impacto no treinamento

Na concepção de Meneses (2007) as organizações cada vez mais demandam estudos acerca do impacto de treinamentos sobre resultados, metas e objetivos organizacionais, de forma que não é suficiente demonstrar que certas ações de TD\&E foram capazes de gerar satisfação, aprendizagem e melhorias de desempenho individual pós-treinamento. É importante, também, verificar se houve aplicação no trabalho dos CHAs aprendido, o que nos levou a fazer esta avaliação e a adotar o conceito de treinamento na visão de Abbad, Pantoja e Pilati (2001), com relação ao longo prazo exercido pelo treinamento nos níveis de desempenho, motivação e atitudes do participante.

Neste referencial fez-se uma revisão de literatura dos conceitos de TD\&E descreveram-se os processos de um modelo sistêmico de treinamento: avaliação de necessidades, implementação e avaliação, os modelos de avaliação, transferência de 
treinamento e avaliação de impacto, pois são a base teórica que servem de suporte para esta pesquisa.

Após análise dos principais autores consultados se evidencia as diferenças entre educação, treinamento e desenvolvimento: a educação assume uma complexidade maior, é uma forma de aprendizagem que assegura a formação o desenvolvimento físico, intelectual e moral de um ser humano, resultante desse processo. No treinamento a diferença está na utilização do aprendido para a melhoria do desempenho no trabalho; já no desenvolvimento, o objetivo é produzir melhorias no desempenho geral, bem como afirmam que cada ação específica de educação, treinamento e desenvolvimento oferecem vantagens por serem consideradas instrumentos eficazes de aprendizagem, assim como exercem papel transformador na capacidade dos indivíduos. Na concepção dos vários autores educação assume uma complexidade maior engloba o conceito de desenvolvimento, e treinamento tem uma proposta comum que é a habilidade e atitude requeridas para o desempenho do trabalho.

$\mathrm{Na}$ visão dos autores citados treinamento é considerado uma ferramenta indispensável para o desenvolvimento humano e da organização, e sua relevância não estar apenas no que se consegue alcançar, mas principalmente no que se deixa desperdiçar em função dos treinamentos.

Isso aponta para um outro ponto comum entre os autores, a importância de se fazer o levantamento das necessidades de treinamento, de se rever objetivos, metodologia e metas para se encontrar caminhos que viabilizem mudanças de forma a capacitar melhor os servidores, porque o insucesso de muitos programas de treinamento ocorre pela ausência ou falta de uma avaliação de necessidade adequada.

Observou-se, por conseguinte, que a eficiência de um treinamento entre outros não depende somente da correta identificação das necessidades e do adequado planejamento, mas também, para detectar falha na execução das tarefas, indicar correções de rumos alternativos para saná-los, e também visa o aperfeiçoamento de desempenhos, o aumento da produtividade e das relações interpessoais.

Os autores propõem que o treinamento também seja avaliado para determinar sua efetividade, para avaliar a extensão em que os programas de treinamento aprimoram o aprendizado, afetam o comportamento no trabalho e influenciam no resultado financeiro da organização, para saber se houve impacto no desempenho individual e organizacional de forma a orientar os gerentes a decidir onde estão às áreas-problemas na organização que devem ser mudadas no programa, e se convém ou não, continuar com determinado programa de treinamento. 
Nessa linha Freitas (2005, p. 42-43) argumenta

o impacto de treinamento em TD\&E, só é observado quando à pessoa treinada aplica os CHAs aprendidos e quando essa aplicação gera melhoria significativa na vida pessoal e profissional. Isso significa dizer que o impacto é o resultado positivo de transferência de aprendizagem e que não pode haver transferência de aprendizagem sem haver transferência de impacto de TD\&E.

Não foi nosso propósito aprofundar discussões sobre esses conceitos, mais sim, ressaltar o valor e a importância de se avaliar TD\&E, sendo possível inferir que ao se fazer avaliação de treinamento, faz se uma grande contribuição para melhorar o desempenho dessas pessoas e das organizações. De acordo com Tyler, (1981 apud LIMA, 2008), a avaliação no processo de ensino-aprendizagem surge da necessidade de se conhecer resultados, compararem desempenhos e estabelecer competências. 


\section{METODOLOGIA}

\subsection{Tipo de Pesquisa}

Para a realização de qualquer trabalho é importante a escolha do método.

Cook e Campbell (1979) e Oskop (1981 apud, MOURÃO, 2004) dão maior ênfase aos dados quantitativos, considerando os dados qualitativos insuficientes para a avaliação de programas. Na concepção de Gaskell (2002), é tecnicamente conveniente o emprego simultâneo de métodos qualitativos e quantitativos de análise, visto que alguns aspectos avaliados demandam o uso de diferentes fontes de avaliação. Apesar de não serem suficientes, os métodos qualitativos oferecem importante contribuição, sobretudo, por colocarem os sujeitos no centro do processo de avaliação e por oferecerem explicações para boa parte dos resultados quantitativos.

Para Vergara (2004) a pesquisa é descritiva quando procura identificar quais situações, atitudes ou opiniões estão manifestas em uma determinada população.

Com base nessa afirmação, foi realizada pesquisa quantitativa, qualitativa e descritiva visando obter os dados básicos para o desenvolvimento e compreensão das relações entre os atores sociais e sua situação (VERGARA, 2000).

Quanto aos meios, esta pesquisa se caracterizou como: bibliográfica, documental e de campo, e foram colhidos os dados diretamente com os participantes, onde ocorreu o fenômeno investigado.

\subsection{Característica da Organização e do Treinamento}

A pesquisa foi realizada na Universidade de Brasília. O curso avaliado foi o treinamento presencial sobre Formação e Desenvolvimento Gerencial (FDG), tendo em vista sua relevância estratégica para a Organização e, dessa forma, maiores possibilidades de associar os objetivos instrucionais a resultados de unidades e da organização. O curso teve carga horária de 150 horas, e é oferecido aos servidores que atuam como gerentes, ou que venham a atuar. 


\subsection{População e amostra}

O universo ou população da pesquisa foi constituído de 166 servidores que participaram do curso de Formação e Desenvolvimento Gerencial (FDG). A primeira turma foi treinada no período de agosto a dezembro de 2005; a segunda de março a julho de 2006; a terceira de agosto a dezembro de 2006 e a última de março a julho de 2007.

A última turma do curso de Formação e Desenvolvimento Gerencial (FDG) foi constituída inicialmente de 40 treinandos, destes, sete treinandos desistiram e três foram reprovados. Para efeito desta pesquisa buscou-se coletar dados com os 30 treinandos, para auto-avaliação (avaliação feita pelo próprio participante), porém verificou-se que um dos treinandos saiu da Instituição, 2 encontravam-se afastados com atestado médico, 2 não responderam e 3 não foram localizados, o que resultou na obtenção de 23 respostas. Para coletar dados da hetero-avaliação (avaliação de chefes e pares, ou seja, colegas que trabalham juntos e estão em posição equivalentes) foram distribuídos 23 questionários para chefes, que resultou em 15 respostas, e 23 para colegas de trabalho, que resultou em 17 respostas.

\subsection{Instrumentos de coleta de dados}

Foi preparado um questionário, a partir da análise de conteúdo de material do curso, para coletar dados relativos à percepção dos participantes quanto ao impacto das diversas disciplinas em seu dia-a-dia, de trabalho. Foram levantadas a frequiência de uso, com o uso de uma escala que variou de 0 a 4 ( $0=$ nunca; 1 = quase nunca; 2 = às vezes; 3 = quase sempre; 4 = sempre), a importância para a atuação cotidiana, com o uso de uma escala que variou de 0 a $3(0=$ nenhuma importância; 1 = pouco importante; $2=$ importante; $3=$ muito importante $)$ e a forma como o conteúdo de cada uma das disciplinas têm contribuído para a realização do trabalho dos entrevistados, bem como 13 perguntas para conhecer a percepção quanto aos resultados da participação no curso sobre os resultados de trabalho, considerando os objetivos do curso. O alcance de objetivos também foi levantado junto a chefias e pares dos pesquisados. Os questionários estão no Apêndice .

O questionário, denominado Avaliação de Impacto de Treinamento, foi aplicado aos treinandos do Curso de Formação e Desenvolvimento Gerencial (FDG), oferecido pela Coordenadoria de Capacitação da SRH/UnB. O questionário teve perguntas fechadas em linguagem apropriada aos participantes, e abertas onde os respondentes puderam registrar livremente informações que entenderam relevantes a respeito do assunto, bem como teve itens 
reservados à caracterização funcional e pessoal dos respondentes (NÓBREGA JUNIOR, 2003).

O questionário de auto-avaliação de impacto de treinamento no trabalho tem em conta os objetivos instrucionais específicos. O objetivo deste questionário foi coletar dados sobre o impacto do curso de Formação e Desenvolvimento Gerencial (FDG) no dia-a-dia de trabalho e a aplicação do aprendido, bem como a percepção a respeito do alcance dos objetivos.

\subsection{Procedimento da coleta de dados}

A coleta de dados a partir do questionário foi agendada previamente, por meio de correio eletrônico (e-mail - carta-convite), posteriormente realizada e registrada pela pesquisadora, no local de trabalho dos participantes que compuseram a amostra desta pesquisa. Também foi garantido aos participantes, sigilo total e absoluto quanto às informações coletadas, bem como a omissão de nomes no resultado da pesquisa.

O questionário foi distribuído para preenchimento por meio de aplicação direta, individual, no próprio local de trabalho do treinando e recolhido em seguida.

O questionário de hetero-avaliação foi distribuído para preenchimento pelos chefes e colegas dos treinandos, individualmente, e recolhido posteriormente.

\subsection{Análise dos dados e resultados}

A partir dos dados coletados foi efetuada análise de conteúdo das questões abertas, seguindo orientações de Bardin (2002) e Franco (2003). Na análise de conteúdo, Bardin (2002) aponta como pilares a fase da descrição ou preparação do material, a inferência ou dedução e à interpretação. Na visão dessa autora, o tratamento, a inferência e a interpretação, permitem que os conteúdos recolhidos se constituam em dados quantitativos e/ou análises reflexivas, em observações individuais e gerais das entrevistas.

Os dados quantitativos foram inicialmente tabulados, e submetidos à análise estatística descritiva (distribuição de freqüência, média e desvio-padrão), tendo sido processados por meio do "Software" estatístico SPSS (Statistic Package for the Social Sciences), versão 16 


\section{RESULTADOS}

Inicialmente estão apresentados os dados relativos à auto-avaliação e, na seqüência os dados relativos à hetero-avaliação.

\subsection{Resultados relativos à auto-avaliação}

Fez-se uma análise dos resultados dos dados coletados junto aos treinandos para caracterização do perfil dos pesquisados; e, a seguir análise da freqüência e importância de uso dos conteúdos abordados nas disciplinas "Universidade Instituição"; "Os sistemas da Universidade"; "Gestão da Universidade"; "Humanização da Universidade" e "Trabalho Final", nas atividades desempenhadas.

Tabela 1 - Distribuição dos pesquisados de acordo com o gênero e idade

\begin{tabular}{|c|c|c|c|}
\hline & Sexo & Freqüiência & $\%$ \\
\hline \multirow{3}{*}{ 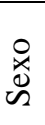 } & Masculino & 11 & 47,8 \\
\hline & Feminino & 12 & 52,2 \\
\hline & Total & 23 & 100 \\
\hline \multirow{5}{*}{ 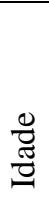 } & De 20 a 30 & 2 & 8,7 \\
\hline & De 31 a 40 & 8 & 34,8 \\
\hline & De 41 a 50 & 9 & 39,1 \\
\hline & De 51 a 60 & 3 & 13,0 \\
\hline & Total & 23 & 100,0 \\
\hline
\end{tabular}

Fonte: Dados da pesquisa

Dos 23 questionários distribuídos, foram respondidos 11 por profissionais do sexo masculino e 12 por profissionais do sexo feminino. Quanto à idade dos pesquisados, há maior número de pesquisados na faixa dos 40 aos 50 anos. A faixa de idade dos pesquisados variaram de 20 a 60 anos, conforme Tabela 1.

Tabela 2 - Distribuição dos pesquisados de acordo com a escolaridade e formação

\begin{tabular}{|c|c|c|c|}
\hline & & Freqüência & $\%$ \\
\hline \multirow{5}{*}{ 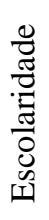 } & Primeiro Grau & 0 & 0 \\
\hline & Segundo Grau & 13 & 56,5 \\
\hline & Terceiro Grau & 10 & 43,5 \\
\hline & Pós-Graduação & 1 & 4,3 \\
\hline & Total & 23 & 100 \\
\hline \multirow{10}{*}{ 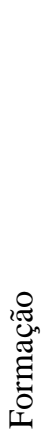 } & Administração & 1 & 4,3 \\
\hline & Biblioteconomia & 1 & 4,3 \\
\hline & Ciências contábeis & 1 & 4,3 \\
\hline & Filosofia & 1 & 4,3 \\
\hline & Pedagogia & 1 & 4,3 \\
\hline & Psicologia e Informática & 1 & 4,3 \\
\hline & Secretariado executivo & 1 & 4,3 \\
\hline & Teologia & 1 & 4,3 \\
\hline & Sem resposta & 14 & 60,9 \\
\hline & Total & 23 & 100 \\
\hline
\end{tabular}

Fonte: Dados da pesquisa 
Entre os participantes da amostra 56,5\% concluíram o segundo grau, 43,5\% concluíram o terceiro grau e 4,3\% dos respondentes concluíram pós-graduação. Verifica-se na distribuição de escolaridade que há diferentes níveis de escolaridade sendo que os de segundo grau e com curso universitário apresentaram as maiores frequiências. (Tabela 2 ).

Tabela 3 - Distribuição dos pesquisados de acordo com o tempo de trabalho, subordinados, quantidade de subordinados, tipo de atividade e tempo na área.

\begin{tabular}{|c|c|c|c|}
\hline & & Freqüência & $\%$ \\
\hline \multirow[t]{5}{*}{ Tempo } & De 1 a 10 & 7 & 30,4 \\
\hline & De 11 a 20 & 11 & 47,8 \\
\hline & De 21 a 30 & 4 & 17,4 \\
\hline & Sem resposta & 1 & 4,3 \\
\hline & Total & 23 & 100 \\
\hline \multirow[t]{3}{*}{ Subordinados } & Não & 9 & 39,1 \\
\hline & Sim & 14 & 60,9 \\
\hline & Total & 23 & 100 \\
\hline \multirow{5}{*}{$\begin{array}{l}\text { Quant. } \\
\text { Subordinados }\end{array}$} & De 1 a 10 & 10 & 43,5 \\
\hline & De 11 a 20 & 3 & 13,0 \\
\hline & De 21 a 30 & 1 & 4,3 \\
\hline & Sem resposta & 9 & 39,1 \\
\hline & Total & 23 & 100 \\
\hline \multirow{4}{*}{$\begin{array}{l}\text { Tipo de } \\
\text { Atividade }\end{array}$} & Apoio acadêmico & 6 & 26,1 \\
\hline & Apoio administrativo & 14 & 60,9 \\
\hline & Outros & 3 & 13,0 \\
\hline & Total & 23 & 100 \\
\hline \multirow{2}{*}{$\begin{array}{l}\text { Outras } \\
\text { Atividades }\end{array}$} & Todas as unidades & 3 & 13,0 \\
\hline & Total & 23 & 100 \\
\hline \multirow{4}{*}{$\begin{array}{l}\text { Tempo } \\
\text { Na área }\end{array}$} & De 1 a 10 & 15 & 65,2 \\
\hline & De 11 a 20 & 7 & 30,4 \\
\hline & De 21 a 30 & 1 & 4,3 \\
\hline & Total & 23 & 100 \\
\hline
\end{tabular}

Fonte: dados da pesquisa

Observa-se na Tabela 3 que o tempo de trabalho na Instituição variou de 01 a 30 anos; $30,4 \%$ tinham tempo de trabalho de 01 a 10 anos, 47,8\% tinham tempo de 11 a 20 anos e $17,4 \%$ tinham tempo de trabalho superior a 21 anos, e 4,3\% não responderam.

De acordo com os pesquisados 39,1\% não tinham subordinados e 60,9\% tinham subordinados. Destes, 43,5\% tinham de 01 a 10 subordinados, 13\% tinham número de subordinados em número superior a 11 e 4,3\% mais de 20 subordinados.

Desta amostra 26,1\% trabalhavam em atividade acadêmica e 60,9\% em unidade administrativa, $13 \%$ em outras, ou seja, administrativa e acadêmica (Tabela 3 ).

No que se refere ao tempo na área de atividade, variaram de 1 a 30 anos, sendo que destes 65,2\% pesquisados tinham de 1 a 10 anos de trabalho na área e 30,4\% mais de 11 anos de trabalho e 4,3\% acima de 20 anos de trabalho. (Tabela 3 ). 
A freqüência e importância dos conteúdos abordados nas disciplinas que compuseram o curso ("Universidade Instituição"; "Os Sistemas da Universidade”; "Gestão da Universidade"; "Humanização da Universidade" e "Trabalho Final”) estão apresentadas nas Tabelas de 4 a 8 , respectivamente.

Tabela 04 - Distribuição das respostas de acordo com a freqüência e importância de uso do conteúdo abordado na disciplina "Universidade Instituição"

\begin{tabular}{|c|c|c|c|c|c|c|c|c|c|}
\hline Conteúdo & Não & Nunca & Sempre & Média & $\begin{array}{l}\text { Desvio } \\
\text { Padrão }\end{array}$ & $\begin{array}{l}\text { Nenhuma } \\
\text { importância }\end{array}$ & $\begin{array}{l}\text { Muito } \\
\text { importante }\end{array}$ & Média & Desvio padrão \\
\hline $\begin{array}{l}\text { Conceitos , objetivos de aprendizagem } \\
\text { organizacional e competências gerenciais. }\end{array}$ & 0 & 8 & 15 & 2,78 & 0,90 & 1 & 22 & 2,61 & 0,58 \\
\hline $\begin{array}{l}\text { Recepção; sensibilização; integração; } \\
\text { formação dos grupos de trabalho. }\end{array}$ & 1 & 10 & 12 & 2,87 & 1,29 & 0 & 23 & 2,52 & 0,51 \\
\hline $\begin{array}{l}\text { Origens e heranças do sistema de ensino } \\
\text { superior brasileiro; a história das } \\
\text { universidades brasileiras e da UnB; o } \\
\text { processo de tomada de decisão nas IES. }\end{array}$ & 1 & 13 & 9 & 2,35 & 1,58 & 5 & 18 & 1,96 & 0,63 \\
\hline  & 0 & 6 & 16 & 3,35 & 1,46 & 1 & 22 & 2,65 & 0,57 \\
\hline $\begin{array}{l}\text { Organização formal }- \text { formas de } \\
\text { organização e gestão; estrutura; linha, } \\
\text { modelos e estilos gerenciais; assessorias, } \\
\text { autoridade; poder, planejamento, controle, } \\
\text { acompanhamento, execução e avaliação de } \\
\text { programas, projetos e eventos. }\end{array}$ & 0 & 12 & 11 & 2,61 & 0,94 & 2 & 21 & 2,39 & 0,65 \\
\hline $\begin{array}{l}\text { Noções de Direito Administrativo e Teoria } \\
\text { Geral do Direito: Administração pública e } \\
\text { o princípio da legalidade. }\end{array}$ & 2 & 12 & 9 & 2,70 & 1,69 & 2 & 21 & 2,30 & 0,76 \\
\hline $\begin{array}{l}\text { Hierarquia das normas e sua aplicação; } \\
\text { principais normas da Universidade de } \\
\text { Brasília: Leis e Normas do serviço público } \\
\text { e do ensino superior brasileiro. }\end{array}$ & 0 & 14 & 8 & 2,61 & 1,55 & 1 & 21 & 2,70 & 1,49 \\
\hline $\begin{array}{l}\text { Conseqüências do descumprimento; } \\
\text { relações trabalhistas; direitos e deveres dos } \\
\text { agentes públicos da UnB. }\end{array}$ & 1 & 12 & 9 & 2,74 & 1,98 & 3 & 20 & 2,39 & 0,83 \\
\hline $\begin{array}{l}\text { Lei n. 11.091/05-estabelece a estruturação } \\
\text { do Plano de Carreira dos Cargos Técnico- } \\
\text { Administrativo em Educação das } \\
\text { Instituições Federais de Ensino e Lei n. } \\
11.211 / 05-\text { Institui o Plano Especial de } \\
\text { Cargos da Cultura e a Gratificação } \\
\text { Específica de Atividade Cultural-GGAC. } \\
\text { Aspectos Positivos do Plano. }\end{array}$ & 0 & 13 & 9 & 2,57 & 1,90 & 4 & 19 & 2,17 & 0,93 \\
\hline $\begin{array}{l}\text { Planejamento da UnB: Histórico e situação } \\
\text { atual; proposta de ensino superior e } \\
\text { modelo de organização; cenários recentes, } \\
\text { evolução do planejamento institucional; } \\
\text { arquitetura do sistema de planejamento; } \\
\text { elementos essenciais do sistema de } \\
\text { planejamento da UnB; Avaliação da } \\
\text { experiência recente. }\end{array}$ & 0 & 13 & 9 & 2,13 & 2,00 & 3 & 20 & 2,35 & 0,83 \\
\hline
\end{tabular}

Tomando por base os dados coletados nesta pesquisa, os conteúdos que se destacaram como "Sempre" utilizados, com 16 respondentes, foram: "Organização informal, pessoas e organizações; relações, complexidade, motivação, desempenho de papeis, integração, liderança, resultados ambiente, clima, dinâmica, cognição, relações de intercâmbio", e 
"Conceitos, objetivos de aprendizagem organizacional e competências gerenciais" com 15 respondentes.

É interessante notar o número de pesquisados que afirma nunca ter utilizado os conteúdos abordados na disciplina, que variou de 6 a 14 dos pesquisados.

Apesar de muitos respondentes terem indicado "Nunca" terem utilizado os conteúdos, a maioria os considera como sendo importantes. Seria interessante investigar porque isso está ocorrendo, uma vez que esses conteúdos são importantes para as atividades em geral.

Os conteúdos, considerados "Não abordado", foram desconsiderados em virtude de terem alcançados percentuais irrelevantes para esta pesquisa. É possível que os treinandos que escolheram essa resposta tenham faltado à aula, ou não tenham lido o conteúdo disponibilizado.

As médias de freqüência de uso variaram de 2,13 (desvio padrão igual a 2) a 3,35 (desvio padrão igual a 1,46), correspondendo a uma média de variação de uso de "às vezes" a “quase sempre". Já a média de importância variou de 1,96 (desvio padrão igual a 0,63) a 2,65 (desvio-padrão igual a 0,57), indicando importâncias que variam de importante a muito importante.

A maior média de freqüência de uso, com 3,35, nesta disciplina, foi o conteúdo "Organização informal, pessoas e organizações; relações, complexidade, motivação; desempenho de papéis; integração; liderança; resultados; ambiente; clima; dinâmica; cognição; relações de intercâmbio com desvio padrão de 1,46.

A dispersão quanto às respostas de freqüência de uso variou de 0,90 a 2 e as de importância, entre 0,51 a 1,49, o que indica haver grande variabilidade nas respostas e menor divergência, entre os pesquisados, quanto à importância do conteúdo.

Os conteúdos que obtiveram média de frequiência de uso iguais a 2,61 foram “Organização formal, formas de organização e gestão, estrutura, linha, modelos e estilos gerenciais, assessorias, autoridade, poder, planejamento, controle, acompanhamento, execução e avaliação de programas, projetos e eventos e "Hierarquia das normas e sua aplicação, principais normas da Universidade de Brasília: leis e normas do serviço público e do ensino superior brasileiro", com desvio padrão diferentes de 0,94 e 1,55, esta matéria também obteve maior média de importância com 2,70 . 
Tabela 5 - Distribuição das respostas de acordo com a freqüência e importância de uso do conteúdo abordado na disciplina "Os sistemas da Universidade"

\begin{tabular}{|c|c|c|c|c|c|c|c|c|c|}
\hline Conteúdo & Não & Nunca & Sempre & Média & $\begin{array}{l}\text { Desvio } \\
\text { padrão }\end{array}$ & $\begin{array}{l}\text { Nenhuma } \\
\text { importância }\end{array}$ & $\begin{array}{l}\text { Muito } \\
\text { importante }\end{array}$ & Média & $\begin{array}{l}\text { Desvio } \\
\text { padrão }\end{array}$ \\
\hline $\begin{array}{l}\text { Introdução à TGS; visão sistêmica de } \\
\text { mundo e da organização UnB. }\end{array}$ & 0 & 13 & 9 & 2,35 & 1,84 & 5 & 18 & 1,96 & 0,76 \\
\hline $\begin{array}{l}\text { Sistema de Administração de Pessoal } \\
\text { SIPES; SIAPE; SISAC (TCU); pequenos } \\
\text { sistemas da SRH; Legislação e Normas } \\
\text { (Externa e Interna). }\end{array}$ & 0 & 12 & 10 & 2,70 & 1,86 & 2 & 21 & 2,39 & 0,89 \\
\hline $\begin{array}{l}\text { Novo sistema de RH via WEB; } \\
\text { funcionalidades, formas de consultas } \\
\text { internas e externas. }\end{array}$ & 1 & 13 & 7 & 2,96 & 2,44 & 4 & 18 & 2,52 & 1,64 \\
\hline $\begin{array}{l}\text { Página da SRH; funcionalidades; serviços; } \\
\text { manual do servidor; manual de Boas- } \\
\text { Vindas. }\end{array}$ & 0 & 19 & 3 & 2,87 & 1,84 & 2 & 21 & 2,35 & 0,64 \\
\hline $\begin{array}{l}\text { Ciclo de planejamento integrado: governo } \\
\text { federal x FUB; estrutura; instrumentos de } \\
\text { acompanhamento do planejamento e de } \\
\text { operacionalização do sistema de } \\
\text { planejamento; relatórios de planejamento e } \\
\text { avaliação institucional. }\end{array}$ & 2 & 12 & 8 & 2,74 & 2,39 & 4 & 18 & 2,39 & 1,64 \\
\hline $\begin{array}{l}\text { SIGRA - Sistema de Informação } \\
\text { Acadêmica de Graduação; Estrutura de um } \\
\text { curso de Graduação; projeto pedagógico. }\end{array}$ & 3 & 11 & 8 & 3,00 & 2,57 & 4 & 18 & 2,26 & 0,91 \\
\hline $\begin{array}{l}\text { Ensino a distância; formas de ingresso; } \\
\text { matrícula em disciplinas; aproveitamento } \\
\text { de estudos; acompanhamento acadêmico; } \\
\text { trancamento de matrícula; formas de } \\
\text { desligamento; formatura; Enade. }\end{array}$ & 1 & 14 & 7 & 2,30 & 2,24 & 6 & 17 & 2,04 & 0,87 \\
\hline $\begin{array}{l}\text { Sistema de Convênios - instrumentos } \\
\text { contratuais. Instrução processual: contratos; } \\
\text { convênios; termo aditivo; acordo ou } \\
\text { protocolo de intenções. }\end{array}$ & 1 & 10 & 10 & 2,83 & 2,65 & 4 & 18 & 2,48 & 1,64 \\
\hline $\begin{array}{l}\text { Banco de Dados e Informação: Noções de } \\
\text { Informática; o cenário da Universidade; } \\
\text { conceitos; responsabilidade; histórico, ciclo } \\
\text { de vida e concepção de sistema, equipe. }\end{array}$ & 2 & 13 & 7 & 2,91 & 2,23 & 3 & 20 & 2,26 & 0,81 \\
\hline $\begin{array}{l}\text { Abordagem sistêmica; construção; } \\
\text { levantamento e exemplos; implementação; } \\
\text { maturidade; declínio, manutenção. }\end{array}$ & 1 & 10 & 8 & 3,43 & 3,07 & 4 & 16 & 2,83 & 2,53 \\
\hline $\begin{array}{l}\text { Administração de sistemas; informação e } \\
\text { sistema na universidade; sistemas } \\
\text { administrativos, acadêmicos; e de apoio e } \\
\text { SCA. }\end{array}$ & 2 & 10 & 9 & 3,30 & 2,58 & 6 & 15 & 2,52 & 2,27 \\
\hline $\begin{array}{l}\text { CONSIAFI - aplicativos para consultas e } \\
\text { elaboração de relatórios gerenciais como } \\
\text { funciona e como utiliza-lo. Relatório } \\
\text { gerencial orçamentário e financeiro para } \\
\text { documentos. }\end{array}$ & 1 & 13 & 7 & 2,52 & 2,72 & 5 & 16 & 2,48 & 2,29 \\
\hline $\begin{array}{l}\text { Sistema de contabilidade e Finanças: } \\
\text { contabilidade pública e governo federal; } \\
\text { objeto da contabilidade; base legal a Lei } \\
4.320 / 64 \text {. }\end{array}$ & 1 & 13 & 7 & 2,61 & 2,67 & 5 & 17 & 2,17 & 1,80 \\
\hline $\begin{array}{l}\text { SIAFI - } \\
\text { Administração Fistema } \text { Financeiro do Goverado de } \\
\text { Federal - Execução orçamentária e } \\
\text { Financeira, Despesa Pública; receitas; } \\
\text { Legislação aplicável. }\end{array}$ & 0 & 12 & 8 & 2,50 & 2,50 & 5 & 17 & 2,22 & 1,85 \\
\hline $\begin{array}{l}\text { Sistema de Material (Aquisição, estoque e } \\
\text { distribuição): histórico das compras } \\
\text { internacionais; competências e atribuições; } \\
\text { fases e processos de importações. }\end{array}$ & 0 & 12 & 8 & 2,73 & 2,45 & 5 & 17 & 2,52 & 1,72 \\
\hline
\end{tabular}


Continuação da Tabela 5 - Distribuição das respostas de acordo com a freqüiência e importância de uso do conteúdo abordado na disciplina "O sistemas da Universidade"

\begin{tabular}{|c|c|c|c|c|c|c|c|c|c|}
\hline Conteúdo & Não & Nunca & Sempre & Média & $\begin{array}{l}\text { Desvio } \\
\text { padrão }\end{array}$ & $\begin{array}{l}\text { Nenhuma } \\
\text { importância }\end{array}$ & $\begin{array}{l}\text { Muito } \\
\text { importante }\end{array}$ & Média & $\begin{array}{l}\text { Desvio } \\
\text { padrão }\end{array}$ \\
\hline 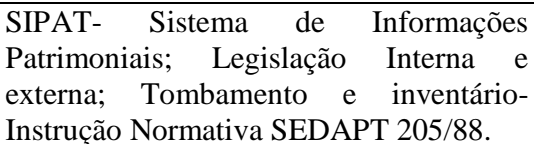 & 0 & 13 & 8 & 2,74 & 2,35 & 5 & 17 & 2,48 & 1,78 \\
\hline $\begin{array}{l}\text { Registro, incorporação; } r \text { controle; } \\
\text { movimentação; transferência; } \\
\text { recolhimento; baixa patrimonial; manual } \\
\text { de normas de registro e controle de bens } \\
\text { móveis. }\end{array}$ & 0 & 14 & 6 & 2,78 & 2,77 & 4 & 17 & 2,83 & 2,12 \\
\hline $\begin{array}{l}\text { Sistema de manutenção dos } \\
\text { equipamentos - política de manutenção } \\
\text { de equipamentos na FUB; resultados } \\
\text { obtidos 2001/05; proposta de mudanças; } \\
\text { manutenção básica; registros de } \\
\text { equipamento da FUB. }\end{array}$ & 0 & 12 & 9 & 2,87 & 2,32 & 3 & 19 & 2,65 & 1,66 \\
\hline $\begin{array}{l}\text { Sistema de empreendimento imobiliário, } \\
\text { condução da política de Gestão } \\
\text { Patrimonial, Planejamento; supervisão, } \\
\text { incorporação, alienação e permuta de } \\
\text { bens imóveis de propriedade da FUB; } \\
\text { normas e legislação. }\end{array}$ & 1 & 15 & 5 & 2,30 & 2,72 & 4 & 18 & 2,22 & 1,78 \\
\hline $\begin{array}{l}\text { Auditoria }- \text { organograma; instrução } \\
\text { normativa } 02 / 2 ; \text { conceitos; função } \\
\text { funcionamento; avaliação da auditoria } \\
\text { interna; atribuições. }\end{array}$ & 1 & 13 & 7 & 2,70 & 2,65 & 5 & 17 & 2,30 & 1,76 \\
\hline $\begin{array}{l}\text { Plano anual de Atividade de Auditoria } \\
\text { Interna - PAAAI; relatório, prestação de } \\
\text { contas anual. }\end{array}$ & 2 & 11 & 8 & 2,70 & 2,91 & 4 & 16 & 3,09 & 2,48 \\
\hline
\end{tabular}

Fonte: Dados da pesquisa

De acordo com a Tabela 5, na disciplina "Os sistemas da Universidade", verifica-se que 19 respondentes informaram "Nunca" ter utilizado os conteúdos "Página da SRH, funcionalidades, serviços, manual do servidor; manual de Boas-Vindas"; "Sempre" foi utilizada por 9 respondentes. A situação desta disciplina é semelhante à anterior quanto ao fato de que todos os conteúdos foram indicados como nunca terem sido utilizados por, no mínimo, 10 dos pesquisados.

É possível que a pouca utilização desses conteúdos no trabalho se deva ao fato de não estarem relacionadas com a área de trabalho dos pesquisados.

Os conteúdos indicados por um maior número de treinandos como sempre utilizados foram

- Sistema de Convênios, instrumentos contratuais, instrução processual: contratos, convênios, termo aditivo, acordo ou protocolo de intenções (10 pesquisados).

- Sistema de Administração de Pessoal SIPES; SIAPE; SISAC (TCU); pequenos sistemas da SRH e Legislação e Normas (Externa e Interna); (10 pesquisados).

- Introdução à TGS, visão sistêmica de mundo e da organização UnB ( 9 pesquisados). 
- Administração de sistemas, informação e sistema na universidade, sistemas administrativos, acadêmicos, e de apoio e SCA (9 pesquisados).

- Sistema de manutenção dos equipamentos, política de manutenção de equipamentos na FUB, resultados obtidos 2001/05, proposta de mudanças, manutenção básica, registros de equipamento da FUB ( 9 pesquisados).

Para $70 \%$ os conteúdos abordados nessa disciplina foram considerados "Muito importantes", e somente 17,4\% consideram esses conteúdos sem "Nenhuma Importância" para suas atividades. Mais uma vez ocorreu de vários dos pesquisados, apesar de considerarem o conteúdo importante e necessário para os processos administrativos e acadêmicos em geral, responderem que nunca o utilizaram. Seria importante um aprofundamento da pesquisa para tentar descobrir porque isso ocorre.

Os conteúdos, considerados "Não abordado", foram desconsiderados em virtude de terem alcançados percentuais irrelevantes para esta pesquisa. Da mesma forma que apontado anteriormente, é possível que os treinandos tenham faltado à aula, ou não tenham lido o conteúdo disponibilizado.

A maior média de frequiência de uso obtida nesta disciplina foi o conteúdo “Abordagem sistêmica, construção, levantamento e exemplos, implementação, maturidade, declínio, manutenção", com 3,43; porém com um desvio-padrão de 3,07. Já a menor média de freqüência de uso foi 2,30 (desvio padrão de 2,24 e de 2,72, respectivamente) para:

- Ensino a distância, formas de ingresso, matrícula em disciplinas, aproveitamento de estudos, acompanhamento acadêmico, trancamento de matrícula, formas de desligamento, formatura, Enade.

- Sistema de empreendimento imobiliário, condução da política de Gestão Patrimonial, Planejamento, supervisão, incorporação, alienação e permuta de bens imóveis de propriedade da FUB, normas e legislação.

A maior média de importância nesta disciplina foi o conteúdo "Plano anual de Atividade de Auditoria Interna - PAAAI; relatório, prestação de contas anuais”, com 3,09 e desvio padrão 2,48 e, a menor média, 1,96 e desvio padrão de 0,76 foi para o conteúdo “Introdução à TGS, visão sistêmica de mundo e da organização UnB” .

A menor dispersão quanto a respostas de importância (desvio padrão 0,64) foi para o conteúdo "Página da SRH, funcionalidades, serviços, manual do servidor; manual de BoasVindas". 
Tabela 6 - Distribuição das respostas de acordo com a freqüência e importância de uso do conteúdo abordado na disciplina "Gestão da Universidade” .

\begin{tabular}{|c|c|c|c|c|c|c|c|c|c|}
\hline Conteúdo & Não & Nunca & Sempre & Média & $\begin{array}{l}\text { Desvio } \\
\text { padrão }\end{array}$ & $\begin{array}{l}\text { Nenhuma } \\
\text { importância }\end{array}$ & $\begin{array}{l}\text { Muito } \\
\text { importante }\end{array}$ & Média & Desvio padrão \\
\hline $\begin{array}{l}\text { Papel do gestor na condução do seu } \\
\text { trabalho e da equipe; competências } \\
\text { gerenciais, conceituação, } \\
\text { administração de conflitos e do } \\
\text { tempo; delegação; trabalho em } \\
\text { equipe. }\end{array}$ & 0 & 5 & 17 & 3,30 & 1,49 & 0 & 23 & 2,74 & 0,44 \\
\hline $\begin{array}{l}\text { Ética como princípio básico das } \\
\text { relações; atendimento a clientela; } \\
\text { administração do tempo; a } \\
\text { comunicação; desenvolvimento } \\
\text { humano; responsabilidade social. }\end{array}$ & 0 & 2 & 20 & 3,78 & 1,31 & 0 & 23 & 2,83 & 0,38 \\
\hline 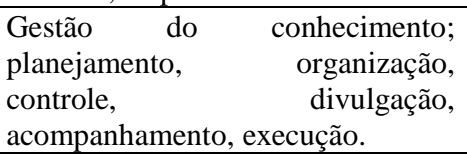 & 0 & 2 & 20 & 3,48 & 1,34 & 0 & 22 & 2,96 & 1,39 \\
\hline $\begin{array}{l}\text { Avaliação de programas, projetos e } \\
\text { eventos; a direção e seus canais; } \\
\text { ordens, comunicação, coordenação, } \\
\text { liderança, motivação; DO: Gestão } \\
\text { da mudança. }\end{array}$ & 1 & 9 & 12 & 3,13 & 1,79 & 0 & 21 & 0,83 & 1,71 \\
\hline $\begin{array}{l}\text { Capacitação de pessoal } \\
\text { Funcionamento do sistema de } \\
\text { treinamento da SRH; objetivo, } \\
\text { orientações para inscrição nos } \\
\text { cursos. }\end{array}$ & 1 & 12 & 9 & 2,83 & 2,05 & 2 & 19 & 3,17 & 1,94 \\
\hline $\begin{array}{l}\text { Orientação sobre catálogo de } \\
\text { treinamento e exemplos de } \\
\text { treinamento; } \\
\text { profissional, formação; atualização } \\
\text { e informática; demandas } \\
\text { específicas dos centros de custos. }\end{array}$ & 0 & 18 & 8 & 2,26 & 1,81 & 4 & 18 & 2,57 & 1,59 \\
\hline 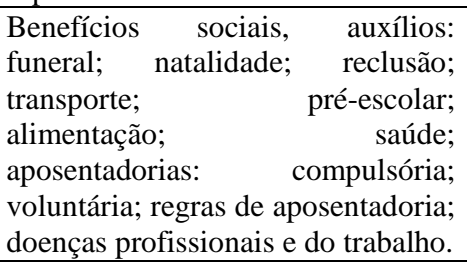 & 1 & 12 & 9 & 2,43 & 2,12 & 2 & 20 & 2,39 & 0,83 \\
\hline $\begin{array}{l}\text { Segurança, medicina do trabalho e } \\
\text { saúde ocupacional, introdução à } \\
\text { segurança do trabalho; acidente do } \\
\text { trabalho; doenças profissionais e do } \\
\text { trabalho; }\end{array}$ & 1 & 10 & 9 & 2,87 & 2,00 & 1 & 22 & 2,57 & 0,59 \\
\hline $\begin{array}{l}\text { Causas de acidentes do trabalho; } \\
\text { investigação; acidentes do trabalho; } \\
\text { inspeção de segurança; tipos e } \\
\text { etapas de inspeção. }\end{array}$ & 1 & 15 & 6 & 2,22 & 2,23 & 2 & 19 & 2,61 & 1,61 \\
\hline $\begin{array}{l}\text { Campanhas de segurança, equipes } \\
\text { de proteção individual; obrigações } \\
\text { da instituição e empregador; } \\
\text { equipes de proteção coletivas; } \\
\text { riscos; controle dos riscos; } \\
\text { legislação aplicada. }\end{array}$ & 1 & 16 & 5 & 2,22 & 2,17 & 3 & 19 & 2,74 & 1,54 \\
\hline
\end{tabular}


Continuação da Tabela 6 - Distribuição das respostas de acordo com a frequiência e importância de uso do conteúdo abordado na disciplina "Gestão da Universidade"

\begin{tabular}{|c|c|c|c|c|c|c|c|c|c|}
\hline Conteúdo & Não & Nunca & Sempre & Média & $\begin{array}{l}\text { Desvio } \\
\text { padrão }\end{array}$ & $\begin{array}{l}\text { Nenhuma } \\
\text { importância }\end{array}$ & $\begin{array}{l}\text { Muito } \\
\text { importante }\end{array}$ & Média & $\begin{array}{l}\text { Desvio } \\
\text { Padrão }\end{array}$ \\
\hline $\begin{array}{l}\text { Subsecretaria de comunicação } \\
\text { Administrativa - Leis, normas e } \\
\text { atos; protocolização, } \\
\text { distribuição de documentos, } \\
\text { expedientes e correspondências } \\
\text { da FUB, bem como publicações } \\
\text { dos atos oficiais da Instituição. }\end{array}$ & 1 & 10 & 11 & 2,91 & 1,85 & 2 & 20 & 2,65 & 1,58 \\
\hline $\begin{array}{l}\text { Avaliação de desempenho: } \\
\text { conceituação, importância e } \\
\text { fatores; dar e receber feedback; } \\
\text { métodos de avaliação da UnB; } \\
\text { métodos de avaliação de } \\
\text { desempenho. }\end{array}$ & 0 & 8 & 14 & 3,09 & 1,53 & 2 & 20 & 2,91 & 1,47 \\
\hline
\end{tabular}

De acordo com a Tabela 6 na disciplina "Gestão da Universidade" os conteúdos que se destacaram como "Sempre" utilizados foram:

- Ética como princípio básico das relações, atendimento a clientela, administração do tempo, a comunicação, desenvolvimento humano, responsabilidade social e Gestão do conhecimento, planejamento, organização, controle, divulgação, acompanhamento (20 pesquisados)

- Papel do gestor na condução do seu trabalho e da equipe, competências gerenciais, conceituação, administração de conflitos e do tempo, delegação, trabalho em equipe (17 pesquisados).

- Avaliação de desempenho: conceituação, importância e fatores, dar e receber feedback, métodos de avaliação da UnB, métodos de avaliação de desempenho (14 pesquisados).

- Avaliação de programas, projetos e eventos, a direção e seus canais, ordens, comunicação, coordenação, liderança, motivação, DO: Gestão da mudança" (12 pesquisados).

- Subsecretaria de Comunicação Administrativa, leis, normas e atos, protocolização, distribuição de documentos, expedientes e correspondências da FUB, bem como publicações dos atos oficiais da Instituição (11 pesquisados).

E os conteúdos com menor número, 34,8\% dos respondentes que "Sempre" utilizaram estes conteúdos: "Capacitação de pessoal, funcionamento do sistema de treinamento da SRH, objetivo, orientações para inscrição nos cursos"; "Benefícios sociais, auxílios: funeral, natalidade, reclusão, transporte, pré-escolar, alimentação, saúde, aposentadorias: compulsória, voluntária, regras de aposentadoria, doenças profissionais e do trabalho"; "Segurança, medicina do trabalho e saúde ocupacional, introdução à segurança do trabalho, acidente do 
trabalho, doenças profissionais e do trabalho"; "Orientação sobre catálogo de treinamento e exemplos de treinamento, qualificação profissional, formação, atualização e informática, demandas específicas dos centros de custos"; "Causas de acidentes do trabalho, investigação, acidentes do trabalho, inspeção de segurança, tipos e etapas de inspeção"; "Campanhas de segurança, equipes de proteção individual, obrigações da instituição e empregador, equipes de proteção coletiva, riscos, controle dos riscos, legislação aplicada".

É interessante notar o número de pesquisados que afirmam nunca ter utilizado os conteúdos abordados na disciplina que variou de 2 a 18 dos pesquisados.

Apesar de muitos respondentes terem indicado "Nunca" terem utilizado os conteúdos, a maioria os considera como sendo importantes e necessários às atividades dos gestores. Seria interessante investigar porque foram pouco utilizados.

Os conteúdos considerados "Não abordado" foram desconsiderados em virtude de terem alcançados percentuais irrelevantes para esta pesquisa. Da mesma forma que apontado anteriormente é possível que os treinandos tenham faltado à aula, ou não tenham lido o conteúdo disponibilizado.

A maior média de freqüência de uso com 3,78 e menor desvio padrão 1,31 foi para o conteúdo "Ética como princípio básico das relações, atendimento a clientela, administração do tempo, a comunicação, desenvolvimento humano, responsabilidade social".

Alcançaram médias iguais de freqüência de uso com 2,22 e desvio padrão diferentes 2,23 e 2,17 respectivamente os conteúdos:

- Causas de acidentes do trabalho, investigação, acidentes do trabalho, inspeção de segurança, tipos e etapas de inspeção.

- Campanhas de segurança, equipes de proteção individual, obrigações da instituição e empregador, equipes de proteção coletivas, riscos, controle dos riscos, legislação aplicada.

A maior média alcançada nessa disciplina, em importância, com 2,91 e desvio padrão igual a 1,47 foi o conteúdo "Avaliação de desempenho: conceituação, importância e fatores, dar e receber feedback, métodos de avaliação da UnB, métodos de avaliação de desempenho".

A menor dispersão quanto a respostas de importância (desvio padrão de 0,38) "Ética como princípio básico das relações, atendimento a clientela, administração do tempo, a comunicação, desenvolvimento humano, responsabilidade social".

Os conteúdos que obtiveram média de importância iguais a 2,74 e desvio padrão diferentes 0,44 e 1,54 respectivamente, "Papel do gestor na condução do seu trabalho e da equipe, competências gerenciais, conceituação, administração de conflitos e do tempo, delegação, trabalho em equipe" e "Campanhas de segurança, equipes de proteção individual, 
obrigações da instituição e empregador, equipes de proteção coletiva, riscos, controle dos riscos, legislação aplicada".

Em seguida os conteúdos com média de importância igual a 2,57 e desvio padrão diferente 1,59 e 0,59 respectivamente, "Orientação sobre programas de treinamento e exemplos de treinamento, qualificação profissional, formação, atualização e informática, demandas específicas dos centros de custos" e "Segurança, medicina do trabalho e saúde ocupacional, introdução à segurança do trabalho, acidente do trabalho, doenças profissionais e do trabalho".

Tabela 7 - Distribuição das respostas de acordo com a freqüência e importância de uso do conteúdo abordado na disciplina "Humanização da Universidade"

\begin{tabular}{|c|c|c|c|c|c|c|c|c|c|}
\hline Conteúdo & $\begin{array}{l}\text { Não } \\
\text { Abordado }\end{array}$ & Nunca & Sempre & Média & $\begin{array}{l}\text { Desvio } \\
\text { padrão }\end{array}$ & $\begin{array}{l}\text { Nenhuma } \\
\text { importante }\end{array}$ & $\begin{array}{l}\text { Muito } \\
\text { Importante }\end{array}$ & Média & $\begin{array}{l}\text { Desvio } \\
\text { padrão }\end{array}$ \\
\hline $\begin{array}{l}\text { Conscientização e capacitação } \\
\text { para o trato com as pessoas } \\
\text { portadoras de necessidades } \\
\text { especiais. }\end{array}$ & 0 & 10 & 12 & 3,09 & 1,83 & 1 & 22 & 2,78 & 0,51 \\
\hline $\begin{array}{l}\text { Qualidade de vida e estresse } \\
\text { ocupacional, relacionamento } \\
\text { interpessoal, gestão de conflito, } \\
\text { postura profissional e condições } \\
\text { de trabalho. }\end{array}$ & 0 & 7 & 15 & 3,04 & 1,60 & 0 & 23 & 2,87 & 0,34 \\
\hline
\end{tabular}

De acordo com a Tabela 7 na disciplina "Humanização da Universidade" 15 respondentes "Sempre" utilizaram o conteúdo "Qualidade de vida e estresse ocupacional, relacionamento interpessoal, gestão de conflito, postura profissional e condições de trabalho" e 12 respondentes "Sempre" utilizaram o conteúdo "Conscientização e capacitação para o trato com as pessoas portadoras de necessidades especiais".

É interessante notar o número de pesquisados que afirmam nunca ter utilizado os conteúdos abordados na disciplina:

- Conscientização e capacitação para o trato com as pessoas portadoras de necessidades especiais (10 pesquisados).

- Qualidade de vida e estresse ocupacional, relacionamento interpessoal, gestão de conflito, postura profissional e condições de trabalho (7 pesquisados).

Apesar, de mais uma vez, os respondentes terem indicado "Nunca" terem utilizado esses conteúdos, a maioria os considera como sendo importantes. Seria interessante um aprofundamento da pesquisa para tentar descobrir porque isso ocorre.

A maior média na freqüência de uso 3,09 foi o conteúdo "Conscientização e capacitação para o trato com as pessoas portadoras de necessidades especiais”. 
A menor dispersão quanto a respostas de freqüência de uso (desvio padrão de 1,60) foi para o conteúdo "Qualidade de vida e estresse ocupacional, relacionamento interpessoal, gestão de conflito, postura profissional e condições de trabalho".

Em relação à importância o conteúdo "Qualidade de vida e estresse ocupacional, relacionamento interpessoal, gestão de conflito, postura profissional e condições de trabalho", obteve a maior média com 2,87 e menor dispersão quanto a respostas de importância (desvio padrão de 0,34$)$.

Tabela 8 - Distribuição das respostas de acordo com a freqüência e importância de uso do conteúdo abordado na disciplina "Trabalho Final".

\begin{tabular}{lcccccccccc}
\hline \multicolumn{1}{c}{ Conteúddo } & Não & Nunca & Sempre & Média & $\begin{array}{l}\text { Desvio } \\
\text { padrão }\end{array}$ & $\begin{array}{l}\text { Nenhuma } \\
\text { importancia }\end{array}$ & $\begin{array}{l}\text { Muito } \\
\text { importante }\end{array}$ & $\begin{array}{c}\text { Média } \\
\text { Desvio } \\
\text { padrão }\end{array}$ \\
\hline $\begin{array}{l}\text { Pesquisa bibliográfica: livros, } \\
\text { revistas especializadas e pesquisa } \\
\text { na Internet. }\end{array}$ & 2 & 10 & 10 & 3,26 & 2,02 & 3 & 18 & 2,91 & 2,08 \\
\hline Orientação do trabalho. & 3 & 6 & 13 & 3,74 & 1,98 & 2 & 19 & 3,04 & 2,07 \\
\hline Elaboração do trabalho. & 1 & 6 & 13 & 3,78 & 2,02 & 2 & 19 & 3,04 & 2,07 \\
\hline Finalização do trabalho. & 4 & 5 & 4 & 4,04 & 2,07 & 2 & 16 & 3,68 & 2,71 \\
\hline
\end{tabular}

Fonte: Dados da pesquisa

De acordo com a Tabela 8 na disciplina "Trabalho Final" os conteúdos indicados por um maior número de treinandos como "Sempre" utilizados foram: "Orientação do trabalho" e "Elaboração do trabalho" com 13 pesquisados respectivamente e "Pesquisa bibliográfica: livros, revistas especializadas e pesquisa na Internet" com 10 pesquisados e "Finalização do trabalho" com 4 respondentes.

É interessante notar o número de pesquisados que afirmam nunca ter utilizado os conteúdos abordados na disciplina:

- Pesquisa bibliográfica: livros, revistas especializadas e pesquisa na Internet (10 pesquisados)

- Orientação do trabalho e Elaboração do trabalho (6 pesquisados respectivamente).

Apesar, de mais uma vez, muitos respondentes terem indicado "Nunca" ter utilizado os conteúdos, a maioria os considera como sendo importantes. Seria interessante um aprofundamento da pesquisa para tentar descobrir porque isso ocorre.

A maior média na frequiência de uso foi o conteúdo "Finalização do trabalho", com 4,04 e desvio padrão igual a 2,07.

A menor dispersão quanto a respostas de frequiência de uso (desvio padrão de 1,98) foi para o conteúdo "Orientação do trabalho". 
A maior média de importância com 3,68 foi para o conteúdo "Finalização do trabalho".

O conteúdo "Orientação do trabalho" e "Elaboração do trabalho" alcançaram média e desvio padrão iguais a 3,04 e 2,07.

Tabela 9 - Distribuição das respostas de acordo com concordância para o alcance dos “Objetivos".

\begin{tabular}{|c|c|c|c|c|c|c|c|}
\hline Conteúdo & $\begin{array}{l}\text { Discordo } \\
\text { Totalmente }\end{array}$ & $\begin{array}{l}\text { Discordo } \\
\text { parcialmente }\end{array}$ & $\begin{array}{l}\text { Nem concordo } \\
\text { Nem discordo }\end{array}$ & $\begin{array}{l}\text { Concordo } \\
\text { parrcialmente }\end{array}$ & $\begin{array}{l}\text { Concordo } \\
\text { totalmente }\end{array}$ & Média & $\begin{array}{l}\text { Desvio } \\
\text { padrão }\end{array}$ \\
\hline $\begin{array}{lcr}\begin{array}{l}\text { Possibilitou o } \\
\text { resolução }\end{array} & \text { conhecimento na } \\
\text { administrativos. } & & \text { problemas } \\
\end{array}$ & 0 & 1 & 0 & 13 & 9 & 3,30 & 0,70 \\
\hline $\begin{array}{l}\text { Possibilitou a utilização dos aspectos } \\
\text { estratégicos na resolução dos } \\
\text { problemas. }\end{array}$ & 1 & 0 & 4 & 15 & 2 & 3,04 & 1,52 \\
\hline $\begin{array}{l}\text { Possibilitou a utilização dos aspectos } \\
\text { táticos e operacionais na resolução } \\
\text { dos problemas administrativos. }\end{array}$ & 1 & 0 & 3 & 17 & 2 & 2,83 & 0,77 \\
\hline $\begin{array}{l}\text { Serviu para a difusão de conceitos, } \\
\text { técnicos e práticas das IFES e de seu } \\
\text { campo profissional (UnB). }\end{array}$ & 1 & 0 & 5 & 10 & 7 & 2,96 & 0,97 \\
\hline $\begin{array}{l}\text { Desenvolveu } \\
\text { necessárias à } \\
\text { GD. }\end{array}$ & 0 & 0 & 8 & 9 & 6 & 2,91 & 0,79 \\
\hline $\begin{array}{l}\text { Integrou conhecimentos gerais e } \\
\text { específicos na execução do trabalho } \\
\text { diário. }\end{array}$ & 0 & 1 & 1 & 11 & 10 & 3,30 & 0,76 \\
\hline $\begin{array}{l}\text { O conhecimento adquirido melhorou } \\
\text { o desempenho no trabalho. }\end{array}$ & 0 & 0 & 0 & 12 & 11 & 3,48 & 0,51 \\
\hline $\begin{array}{l}\text { Houve adequação dos conceitos } \\
\text { informações necessárias à } \\
\text { compreensão do trabalho. }\end{array}$ & 0 & 0 & 1 & 14 & 8 & 3,30 & 0,55 \\
\hline $\begin{array}{l}\text { Houve domínio teórico ou prático dos } \\
\text { assuntos abordados de forma a saber o } \\
\text { que e como funciona. }\end{array}$ & 0 & 1 & 2 & 14 & 6 & 3,09 & 0,73 \\
\hline Adquiriu habilidades de liderança & 0 & 0 & 3 & 14 & 6 & 3,13 & 0,62 \\
\hline $\begin{array}{l}\text { Adquiriu habilidades } \\
\text { relacionamento. }\end{array}$ & 0 & 0 & 1 & 13 & 9 & 3,35 & 0,57 \\
\hline Adquiriu habilidades de negociação. & 0 & 0 & 0 & 17 & 6 & 3,26 & 0,44 \\
\hline Adquiriu habilidades de comunicação. & 0 & 0 & 0 & 13 & 9 & 3,41 & 0,50 \\
\hline
\end{tabular}

Na opinião dos "treinandos" entre os treze indicadores de alcance dos objetivos os itens que receberam maiores destaques foram os conteúdos: "O conhecimento adquirido melhorou o despenho no trabalho" com 11 respondentes que concordaram totalmente e 12 respondentes concordaram parcialmente, com média e desvio padrão igual a 3,48 e 0,51 respectivamente (Tabela 9). 
Se "Integrou conhecimentos gerais e específicos na execução do trabalho diário", 11 respondentes concordaram totalmente 11 respondentes concordaram parcialmente com média e desvio padrão igual a 3,30 e 0,76 respectivamente.

Se "Possibilitou o conhecimento na resolução dos problemas administrativos", 9 respondentes concordaram totalmente 13 respondentes concordaram parcialmente com média e desvio padrão igual a 3,30 e 0,70 respectivamente.

Se "Adquiriu habilidades de relacionamento" 9 respondentes concordaram totalmente 13 respondentes concordaram parcialmente com média e desvio padrão igual a 3,35 e 0,57 respectivamente.

Se "Adquiriu habilidades de comunicação“, 9 respondentes discordaram totalmente 13 concordaram parcialmente, com média e desvio padrão igual a 3,41 e 0,50 respectivamente.

Se "Houve adequação dos conceitos informações necessárias à compreensão do trabalho" 8 respondentes concordam totalmente 14 concordam parcialmente com média e desvio padrão igual a 3,30 e 0,55 respectivamente.

Se "Serviu para a difusão de conceitos, técnicas e práticas das IFES e de seu campo profissional (UnB)" 7 respondentes concordaram totalmente e 10 concordaram parcialmente com média e desvio padrão igual a 2,96 e 0,97 respectivamente.

Os objetivos em que a concordância teve menor número de respostas são relativos aos conteúdos: "Adquiriu habilidades de negociação", 6 respondentes concordaram totalmente 17 respondentes concordaram parcialmente com média e desvio padrão igual a 3,26 e 0,44 respectivamente.

Se o conteúdo "Possibilitou a utilização dos aspectos táticos e operacionais na resolução dos problemas administrativos", 6 respondentes concordaram totalmente 17 respondentes concordaram parcialmente com média e desvio padrão igual a 2,83 e 0,77 respectivamente.

Se "Desenvolveu as habilidades necessárias a operacionalização do GD", 6 respondentes concordaram totalmente 9 respondentes concordaram parcialmente, com média e desvio padrão igual a 2,91 e 0,79 respectivamente.

Se "Houve domínio teórico ou prático dos assuntos abordados para saber o que e como funciona", 6 respondentes concordaram totalmente 14 respondentes concordaram parcialmente com média e desvio padrão igual a 3,09 e 0,73 respectivamente.

Se "Adquiriu habilidades de liderança", 6 respondentes concordaram totalmente 14 respondentes concordaram parcialmente, com média e desvio padrão igual a 3,13 e 0,62 respectivamente. 
Se o conteúdo "Possibilitou a utilização dos aspectos estratégicos na resolução dos problemas" 2 respondentes concordam totalmente 15 respondentes concordam parcialmente , com média e desvio padrão igual a 3,44 e 1,52 respectivamente.

Este resultado parece indicar que os treinandos percebem-se como elementos ativos no processo de transferência de treinamento, porém os conhecimentos adquiridos no curso foram, em sua maioria, aplicados parcialmente às atividades no trabalho.

E $13 \%$ dos respondentes "Nem concordam e Nem discordam" quanto a esse conteúdo ter contribuído para o alcance dos objetivos. 4,3\% discordaram totalmente que esse conteúdo tenha contribuído para o alcance dos objetivos.

A seguir os resultados das questões abertas a respeito da contribuição das disciplinas: "Universidade Instituição"; “Os Sistemas da Universidade"; "Gestão da Universidade"; "Humanização da Instituição" e "Trabalho Final" para o trabalho dos pesquisados:

Em relação à contribuição da disciplina "Universidade Instituição" para o trabalho dos pesquisados, foram apresentados 13 argumentos por 23 pesquisados, cujas respostas, categorizadas, são:

- Aprimorar conhecimentos sobre a estrutura organizacional da Universidade; (quatro respostas)

- Contribuiu para ampliar conhecimentos sobre a Instituição; (uma resposta)

- Contribuiu para o enriquecimento das varias atividades exercidas; (duas respostas)

- Compreender melhor a unidade de trabalho; proporcionar maneiras para o alcance dos objetivos; (uma resposta)

- Contribuiu para a formação e melhor desenvolvimento da função exercida; (uma resposta)

- Contribuiu para o conhecimento da legislação sobre as Instituições de Ensino (uma resposta)

- Entender o papel da UnB; (uma resposta)

- Ter visão mais ampla do funcionamento do sistema; (uma resposta)

- Um respondente afirma que contribuiu "muito pouco" em função da rotatividade de estagiários.

Em relação à contribuição da disciplina "Os sistemas da Universidade" para o trabalho dos pesquisados, foram apresentados 13 argumentos por 23 pesquisados, cujas respostas categorizadas são: 
- Contribuiu para conhecer áreas específicas e como a universidade funciona de modo geral; (duas respostas)

- Atualizar conhecimentos como gerentes; (duas respostas)

- Contribuiu para o desenvolvimento do trabalho pois utiliza estes sistemas diariamente; (duas respostas)

- Contribuiu para melhoria na rotina do trabalho; (uma resposta)

- Conhecer os sistemas que não utiliza no trabalho; (uma resposta)

- Contribuiu para agilizar o atendimento ao público; (uma resposta)

- Contribuiu no processo de facilitação e modernização nas tarefas e para adequá-las as atividades diárias; (uma resposta)

- Ter visão administrativa ampla; (uma resposta)

- Um respondente afirma que "não contribuiu para reter conhecimento em função da grande quantidade de conteúdo"; outro está distanciada das atividades, porém são importante.

Em relação à contribuição da disciplina “Gestão da Universidade" para o trabalho dos pesquisados, foram apresentados 12 argumentos por 23 pesquisados, cujas respostas categorizadas são:

- Melhorar o desempenho como chefe; (duas respostas)

- Contribui para o aperfeiçoamento como líder e no desempenho no exercício da função de gestor, nas dificuldades enfrentadas quando falta o suporte ou treinamento, a falta de conhecimento dos benefícios sociais que não são utilizados, para conhecer a cultura de avaliação de desempenho associada ao salário como benefício; (duas respostas)

- Aprender a dar informação a respeito; (uma resposta)

- Compreender e divulgar as diretrizes da UnB; (uma resposta)

- Conhecer de maneira objetiva os procedimentos de alguns setores; (uma resposta)

- Contribuiu para conhecimento dos direitos e obrigações dos agentes públicos; (uma resposta)

- Contribuiu para a motivação; (uma resposta)

- Agilizar processos e situações; (uma resposta)

- Um respondente afirma que "quase nada não contribuiu"; e outro respondente que "contribuiu pouco em função da rotatividade de servidores". 
Em relação à contribuição da disciplina "Humanização da Universidade" para o trabalho dos pesquisados, foram apresentados 12 argumentos dos 23 pesquisados, cujas respostas categorizadas são:

- Contribuiu para melhor atender os portadores de necessidades especiais e para administrar o estresse no trabalho; (uma resposta)

- Melhorar o aproveitamento físico e psíquico nas atividades; (uma resposta)

- Ter conhecimento sobre deficiente visual e suas necessidades especiais, mas que faltou clareza quanto a qualidade de vida no trabalho e seus benefícios; (uma resposta)

- Compreender as relações pessoais; (uma resposta)

- Entender o que as pessoas enfrentam no seu dia-a-dia; (uma resposta)

- Melhorar o relacionamento com a equipe de trabalho e demais setores; (uma resposta)

- Melhorar o relacionamento interpessoal e postura profissional; (uma resposta)

- Melhorar o relacionamento com os colegas; (uma resposta)

- Perceber e resolver em equipe os problemas de trabalho; (uma resposta)

- Sensibilizar mais para as situações dos portadores de necessidades especiais; (uma resposta)

- Contribuiu para a humanização nas atividades; (uma resposta)

- Melhorar postura ao tratar com portadores de necessidades de especiais; (uma resposta)

Em relação à contribuição da disciplina "Trabalho Final” para o trabalho dos pesquisados, foram apresentados 9 argumentos dos 23 pesquisados, cujas respostas categorizadas são:

- Melhorar o desempenho nas atividades do trabalho; (uma resposta)

- Melhorar o relacionamento interpessoal com os colegas e pessoas de modo geral (duas respostas)

- Desenvolver visão psicossocial do cotidiano no serviço público; (uma resposta)

- Fazer análise dos conhecimentos adquiridos no curso; (uma resposta)

- Contribuiu para fazer o resumo de livro; (uma resposta)

- Contribuiu para a reflexão e valorização sobre a vida pessoal e profissional; (uma resposta)

- Observar certos pontos que anteriormente não fazia e ser sensato; (uma resposta)

- Desenvolver melhor o trabalho final; (uma resposta)

- Um respondente afirma que "Não contribuiu em nada, não acredita em histórias 
fantasiosas" (O Monge e o Executivo, livro destinado para o Trabalho Final). Perguntado se gostariam de compartilhar outras informações, responderam:

- Gostaria de participar de mais cursos dessa natureza para maior aperfeiçoamento no trabalho, bem como, mais cotas para extra-quadros; (duas respostas)

- O treinamento foi excelente contribuiu para a vida profissional e pessoal, amplia a visão e estimula para continuar estudando; (duas respostas)

- A visão macro oferecida no curso ajudou a desenvolver melhor as atividades administrativas e acadêmicas na Instituição, e a estabelecer parâmetros; (duas respostas)

- Gostaria que o treinamento fosse estendido aos chefes em geral; (uma resposta)

- Incluir módulo sobre a Biblioteca; (uma resposta)

- Muito importante, alguns tópicos poderiam ser aprofundados como na disciplina “Gestão da Universidade”: papel do gestor; ética; motivação; (uma resposta) Um respondente afirma "Na área em que trabalha só utiliza $40 \%$ do que foi abordado; e outro "Amo trabalhar na UnB e adorou o curso".

Perguntado quanto à Contribuição para o Trabalho, responderam:

- Contribuiu para maior conhecimento sobre Gestão universitária; (uma resposta)

- Obter uma visão geral da UnB, porém a carga horária insuficiente não permitiu aprofundamento do conteúdo das disciplina; (uma resposta)

- Ampliar o conhecimento e enriquecer a visão tática de trabalho; (uma resposta)

- Possibilitou melhor desenvolvimento profissional; (duas respostas)

- Esclarecer dúvidas e dar uma explanação geral sobre o funcionamento da Instituição; (uma resposta)

- Proporcionar habilidades técnicas e conceituais; (uma resposta)

- Desenvolver auto-estima profissional; (uma resposta)

- Fazer reflexão sobre as situações de trabalho e aprimorar-se profissionalmente; (uma resposta)

Um respondente afirma "Não utiliza o que aprendeu no trabalho. Em função da rotatividade dos servidores e estagiários"; outro respondeu que "contribui às vezes"; e outro "Não contribuiu, porque alguns conteúdos aprendidos no curso não fazem parte das atividades do centro de custo"; e um respondeu que "Não atingiu total melhoria por falta de suporte, condições do departamento onde trabalha". 
Verifica-se na opinião dos "treinandos" que seria interessante encontrar oportunidades de melhor aproveitamento de transferência do aprendido no curso e sua aplicação nas atividades de trabalho, a fim de que a eficácia dos cursos possa ser intensificada, uma vez que a função básica da avaliação de treinamento é o fornecimento de retroalimentação contínua ao sistema de treinamento.

\subsection{Resultados da pesquisa relativos à hetero-avaliação}

Fez-se uma análise dos resultados dos dados coletados junto aos chefes e pares para categorização do perfil dos pesquisados e compararam-se resultados para confirmação do alcance dos objetivos.

Tabela 10 - Distribuição dos pesquisados de acordo com o gênero; a idade; escolaridade e formação

\begin{tabular}{|c|c|c|c|}
\hline & & Freqüência & $\%$ \\
\hline \multirow{3}{*}{ 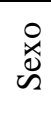 } & Masculino & 20 & 62,5 \\
\hline & Feminino & 12 & 37,5 \\
\hline & Total & 32 & 100 \\
\hline \multirow{5}{*}{$\frac{\mathscr{\theta}}{\tilde{Z}}$} & De 20 a 30 & 9 & 28,1 \\
\hline & De 31 a 40 & 5 & 15,6 \\
\hline & De 41 a 50 & 9 & 28,1 \\
\hline & De 51 a 60 & 7 & 21,9 \\
\hline & Total & 32 & 100 \\
\hline \multirow{5}{*}{  } & Primeiro grau & 0 & 0 \\
\hline & Segundo grau & 13 & 40,6 \\
\hline & Terceiro grau & 13 & 40,6 \\
\hline & Pós-graduação & 6 & 18,8 \\
\hline & Total & 32 & 100 \\
\hline \multirow{17}{*}{ 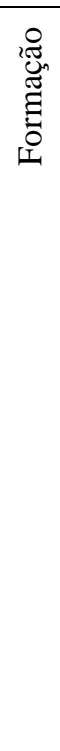 } & Administração & 1 & 3,1 \\
\hline & Biblioteconomia & 2 & 3,6 \\
\hline & Ciências Contábeis & 1 & 3,1 \\
\hline & EAD & 1 & 3,1 \\
\hline & Engenharia civil e ambiental/Pós & 1 & 3,1 \\
\hline & Engenharia mecânica/física & 1 & 3,1 \\
\hline & $\begin{array}{l}\text { Especialização em } \quad \text { Gestão } \\
\text { Universitária }\end{array}$ & 2 & 3,6 \\
\hline & Geografia & 1 & 3,1 \\
\hline & História & 1 & 3,1 \\
\hline & Matemática & 1 & 3,1 \\
\hline & Professor de Psicologia & 1 & 3,1 \\
\hline & Psicologia e Informática & 2 & 3,6 \\
\hline & Recursos Humanos & 1 & 3,1 \\
\hline & Secretariado Executivo & 1 & 3,1 \\
\hline & Serviço Social & 1 & 3,1 \\
\hline & Sem resposta & 3 & 9,4 \\
\hline & Total & 19 & 100 \\
\hline
\end{tabular}

Fonte: dados da pesquisa

No que diz respeito às características demográficas dos profissionais pesquisados "chefes e pares", o universo de respondentes foi composto por $62,5 \%$ de profissionais do sexo masculino e $37,5 \%$ do sexo feminino. Destes, $28,1 \%$ tinham idade entre 20 a 30 e $28,1 \%$ 
tinham idade de 31 a 40 anos, sendo que a faixa de idade varia de 20 a 60 anos. Entre os participantes $40,6 \%$ concluíram o segundo grau e 40,6\% concluíram o terceiro grau e 18,8\% pós-graduação, conforme Tabela 10.

Tabela 11 - Distribuição dos pesquisados de acordo com o tempo de trabalho, subordinados, quantos subordinados, tipo de atividades, outras atividades e atividades na área.

\begin{tabular}{|c|c|c|c|}
\hline & & Freqüência & $\%$ \\
\hline \multirow{6}{*}{$\begin{array}{l}\text { Tempo } \\
\text { (anos) }\end{array}$} & De 1 a 10 & 13 & 40,6 \\
\hline & De 11 a 20 & 7 & 21,9 \\
\hline & De 21 a 30 & 8 & 25,0 \\
\hline & De 31 a 40 & 1 & 3,1 \\
\hline & Sem resposta & 3 & 9,4 \\
\hline & Total & 32 & 100 \\
\hline \multirow[t]{3}{*}{ Subordinados } & Não & 15 & 46,9 \\
\hline & $\mathrm{Sim}$ & 17 & 53,1 \\
\hline & Total & 32 & 100 \\
\hline \multirow[t]{4}{*}{ Quant. Subordinados } & De 1 a 10 & 12 & 37,5 \\
\hline & De 11 a 20 & 2 & 3,6 \\
\hline & Sem resposta & 3 & 9,4 \\
\hline & Total & 17 & 100 \\
\hline \multirow[t]{4}{*}{ Tipo de atividade } & Apoio acadêmico & 10 & 31,3 \\
\hline & Apoio administrativo & 21 & 65,6 \\
\hline & Outros & 1 & 3,1 \\
\hline & Total & 32 & 100 \\
\hline \multirow[t]{2}{*}{ Outras atividades } & $\begin{array}{lll}\begin{array}{l}\text { Professora } \\
\text { departamento }\end{array} & & \text { de } \\
\end{array}$ & 1 & 3,1 \\
\hline & Total & 1 & 100 \\
\hline \multirow[t]{6}{*}{ Tempo na área } & De $3 \mathrm{~m}$ a10 anos & 14 & 43,8 \\
\hline & De 11 a 20 & 5 & 15,6 \\
\hline & De 21 a 30 & 7 & 21,9 \\
\hline & De 31 a 40 & 1 & 3,1 \\
\hline & Sem resposta & 5 & 15,6 \\
\hline & Total & 32 & 100 \\
\hline
\end{tabular}

Fonte: Dados da pesquisa

Quanto aos dados sobre o tempo de trabalho na Instituição esses variaram de 1 ano a 40 anos, sendo que o maior índice de 40,6\% tinham de 1 a 10 anos de trabalho; 21,9\% tinham de 11 a 20 anos de trabalho e $25 \%$ tinham tempo de trabalho superior a 31 anos e 3,1\% não responderam. Entre os participantes 46,9\% não tinham subordinados e 53,1\% tinham subordinados. Destes, 37,5\% tinham de 1 a 10 subordinados e 3,6\% tinham acima de 11 subordinados.

Em relação ao tipo de atividade, 31,3\% atuam em atividades de apoio acadêmico, 65,6\% trabalham em atividades administrativas e 3,1\% trabalham em atividade de ensino.

O tempo na área de atividade dos pesquisados variou de 3 meses a 40 anos: 43,8\% dos pesquisados tinham de 3 meses a 10 anos de trabalho na área; 15,6\% tinham de 11 a 20 anos; 
21,9\% tinham de 21 a 30 anos; $3,1 \%$ tinham tempo de trabalho na área superior a 31 anos e 15,6\% não responderam, conforme dados apresentados na Tabela 11.

Os dados relativos à avaliação do alcance de resultados por parte de "chefias e pares", estão apresentados na Tabela 12.

Os treze indicadores de alcance dos objetivos foram percebidos por um maior número de respondentes, chefes e pares, como tendo sido atendidos: entre 24 e 31 , de um total de 32 .

Alguns dos pesquisados (entre 1 a 4) apontaram discordar (total ou parcialmente) que os objetivos a seguir foram alcançados:

- "Desenvolveu as habilidades necessárias à operacionalização do GD” (4 respondentes).

- "Possibilitou a utilização dos aspectos táticos e operacionais na resolução dos problemas administrativos" (2 respondentes).

- "Possibilitou a utilização dos aspectos estratégicos na resolução dos problemas" (1 respondente).

- "Possibilitou a utilização dos aspectos táticos e operacionais na resolução dos problemas administrativos" (1 respondente).

- "Serviu para a difusão de conceitos, técnicos e práticas das IFES e de seu campo profissional (UnB)" (1 respondente).

- "Integrou conhecimentos gerais e específicos na execução do trabalho diário" (1 respondente).

- "Houve domínio teórico ou prático dos assuntos abordados para saber o que e como funciona" (2 respondente).

- "Adquiriu habilidades de negociação" (1 respondente).

Para alguns dos conteúdos o número de respondentes que nem concordam nem discordam que os conteúdos tenham contribuído para o alcance dos objetivos variou de 6 a 7: "Possibilitou a utilização dos aspectos táticos e operacionais na resolução dos problemas administrativos"; "Integrou conhecimentos gerais e específicos na execução do trabalho diário" e "Serviu para a difusão de conceitos, técnicos e práticas das IFES e de seu campo profissional $(\mathrm{UnB})$ ".

As médias obtidas quanto ao alcance de objetivos indicam concordância parcial, porém há que observar que houve dispersão nas respostas dadas (desvio-padrão variou entre $0,47$ a 1$)$. 
Tabela 12 - Distribuição dos pesquisados de acordo com a concordância para o alcance dos "Objetivos"

\begin{tabular}{|c|c|c|c|c|c|c|c|}
\hline Conteúdo & $\begin{array}{l}\text { Discordo } \\
\text { Totalmente }\end{array}$ & $\begin{array}{c}\text { Discordo } \\
\text { parcialmente }\end{array}$ & $\begin{array}{c}\text { Nem } \\
\text { concordo } \\
\text { Nem } \\
\text { discordo }\end{array}$ & $\begin{array}{c}\text { Concordo } \\
\text { parcialmente }\end{array}$ & $\begin{array}{l}\text { Concordo } \\
\text { totalmente }\end{array}$ & Média & $\begin{array}{l}\text { Desvio } \\
\text { padrão }\end{array}$ \\
\hline $\begin{array}{l}\text { Possibilitou o conhecimento } \\
\text { na resolução dos problemas } \\
\text { administrativos. }\end{array}$ & 1 & 0 & 2 & 13 & 16 & 3,45 & 0,62 \\
\hline $\begin{array}{l}\text { Possibilitou a utilização dos } \\
\text { aspectos estratégicos na } \\
\text { resolução dos problemas. }\end{array}$ & 2 & 0 & 2 & 17 & 11 & 3,19 & 0,83 \\
\hline $\begin{array}{l}\text { Possibilitou a utilização dos } \\
\text { aspectos táticos e } \\
\text { operacionais na resolução dos } \\
\text { problemas administrativos. }\end{array}$ & 1 & 0 & 6 & 13 & 12 & 3,19 & 0,74 \\
\hline $\begin{array}{l}\text { Serviu para a difusão de } \\
\text { conceitos, técnicos e práticas } \\
\text { das IFES e de seu campo } \\
\text { profissional (UnB). }\end{array}$ & 1 & 0 & 7 & 4 & 20 & 3,41 & 0,84 \\
\hline $\begin{array}{l}\text { Desenvolveu as habilidades } \\
\text { necessárias à } \\
\text { operacionalização do GD. }\end{array}$ & 2 & 2 & 1 & 14 & 13 & 3,16 & 1,0 \\
\hline $\begin{array}{l}\text { Integrou conhecimentos } \\
\text { gerais e específicos na } \\
\text { execução do trabalho diário. }\end{array}$ & 0 & 1 & 6 & 19 & 17 & 3,32 & 0,79 \\
\hline $\begin{array}{l}\text { O conhecimento adquirido } \\
\text { melhorou o desempenho no } \\
\text { trabalho. }\end{array}$ & 0 & 0 & 0 & 11 & 20 & 3,66 & 0,47 \\
\hline $\begin{array}{lr}\text { Houve } & \text { adequação dos } \\
\text { conceitos } & \text { informações } \\
\text { necessárias à compreensão do } \\
\text { trabalho. }\end{array}$ & 0 & 0 & 3 & 13 & 14 & 3,36 & 0,66 \\
\hline $\begin{array}{l}\text { Houve } \\
\text { prático domínio teórico ou } \\
\text { abordados para saber o que e } \\
\text { como funciona. }\end{array}$ & 0 & 2 & 2 & 13 & 15 & 3,32 & 0,83 \\
\hline $\begin{array}{lll}\text { Adquiriu habilidades } & \text { de } \\
\text { liderança } & & \\
\end{array}$ & 0 & 0 & 4 & 14 & 13 & 3,29 & 0,69 \\
\hline $\begin{array}{l}\text { Adquiriu habilidades de } \\
\text { relacionamento. }\end{array}$ & 0 & 0 & 4 & 8 & 17 & 3,50 & 073 \\
\hline $\begin{array}{l}\text { Adquiriu habilidades de } \\
\text { negociação. }\end{array}$ & 1 & 0 & 3 & 14 & 14 & 3,25 & 0,89 \\
\hline $\begin{array}{l}\text { Adquiriu habilidades } \mathrm{de} \\
\text { comunicação. }\end{array}$ & 0 & 0 & 1 & 14 & 17 & 3,45 & 0,62 \\
\hline
\end{tabular}

Fonte: Dados da pesquisa

$\mathrm{Na}$ comparação entre auto e heteroavaliação, constata-se, a partir dos dados apresentados nas Tabelas 9 e 12, que os resultados da heteroavaliação (chefes e pares) mostraram predominância para a concordância total, enquanto que na auto-avaliação (treinandos) houve predominância para a concordância parcial. Porém, de um modo geral, as médias obtidas para o alcance de objetivos foi semelhante. A maior diferença de médias foi 
para a "Possibilitou a utilização dos aspectos táticos e operacionais na resolução dos problemas administrativos" e "Serviu para a difusão de conceitos, técnicos e práticas das IFES e de seu campo profissional (UnB)", recomendando-se que seja efetuado teste estatístico para verificar se essa diferença é significativa.

Partindo-se do pressuposto de que o principal produto dos treinamentos em contextos organizacionais é a melhoria do desempenho profissional por meio da aplicação dos conhecimentos, habilidades e atitudes aprendidas, e diante da constatação dos resultados alcançados na análise de respostas fornecidas por "chefes e pares" e por "treinandos", é possível afirmar que, pelo menos para um maior contingente de treinandos, a percepção é de que ocorreu o alcance dos objetivos.

Em relação aos resultados das questões abertas, quando perguntado aos "chefes e pares" a respeito da contribuição da participação do treinando no curso: para o desempenho no trabalho, ou porque razões o participante não utiliza o conteúdo aprendido no trabalho, responderam:

- Contribuiu para melhor desempenho das atividades que estão sendo realizadas com responsabilidade e dedicação (quatro respostas);

- Contribuiu para facilitar e desenvolver com eficácia as tarefas no trabalho (três respostas);

- Contribuiu para aumentar habilidades e melhorar a comunicação, liderar o ambiente de trabalho (três respostas);

- Agregou conhecimentos imprescindíveis ao desenvolvimento da Instituição (duas respostas);

- Melhorou o conhecimento em relação à instituição como um todo (duas respostas);

- Contribuiu como elemento de valorização do trabalho do funcionário, houve notável mudança na auto-estima (uma resposta);

- Ampliou o conhecimento, enriqueceu a visão tática de trabalho (uma resposta);

- Obteve progresso no desenvolvimento de suas atividades e no relacionamento interpessoal (uma resposta);

- Contribuiu para reflexão, aprimoramento e melhoria dos trabalhos (uma resposta);

Um respondente "não colocou em prática os conhecimentos do curso em função de mudança de setor"; para outro, não houve impacto significativo na condução dos trabalhos, por não ocupar função gerencial”, e dois responderam "não ter nada a declarar".

A seguir serão discutidos os resultados de auto e heteroavaliações com análise mais detalhada desta pesquisa. 


\section{DISCUSSÃO DOS RESULTADOS}

Os resultados apresentados serão discutidos à luz dos autores citados, buscando interpretações na literatura revisada. As discussões focalizaram partes que dificultam e/ou facilitam o processo de transferência de aprendizagem, características do indivíduo tais como motivação, atitude e habilidade para transferir aprendizagens de T\&D.

A leitura dos resultados mostrou que os respondentes perceberam que houve transferência de aprendizagem e aplicação em seu trabalho dos conteúdos das disciplinas "Universidade Instituição"; "Os Sistemas da Universidade"; "Gestão da Universidade"; "Humanização da Universidade"; "Trabalho Final” e alcance dos objetivos. Muitos estudos se referem à transferência de treinamento, concordando com Freitas (2005) e com Abbad e Borges-Andrade (2004), que quando se diz transferência de treinamento "na verdade se referem à aplicação no ambiente de trabalho das aprendizagens adquiridas em programas de T\&D”. Ainda na percepção dos respondentes, houve também, aplicação e melhoria do desempenho. Isso parece sinalizar que esforços nas ações de treinamento da organização, foram em grande parte, revertidos para o exercício de suas funções, ou seja, utilizaram o aprendido no trabalho.

À análise de conteúdo dessas disciplinas indicaram segundo a percepção dos respondentes serem "Muito importante" embora tenha havido índices elevados como "Nunca" utilizados, grande parte apontou que "Sempre" aplicam os conteúdos aprendidos no curso.

Para se observar o desempenho do indivíduo no trabalho, ou seja, a aplicação do aprendido no ambiente de transferência é preciso mais do que saber (habilidades). O indivíduo também precisa querer fazer a tarefa (motivação) e ter condições no ambiente para fazê-lo (ABBAD, 1999). Enfocam Tannembaum e Yukl (1992) que fatores organizacionais são facilitadores ou inibidores dos comportamentos de transferência de treinamento. Os resultados apresentados sugerem, conforme pesquisa qualitativa situações e condições de trabalho que podem ter inibido ou impedido esses profissionais motivados e competentes, a não utilizarem esses conteúdos. Algumas possíveis explicações, de acordo com as respostas dos pesquisados foram: a) conteúdo pouco relacionado às atividades desenvolvidas por esses profissionais na organização; b) falta de suporte e c) conseqüências associadas ao uso de novas habilidades. Como mostram os resultados dos estudos de: Sallorenzo (2000); Abbad e Sallorenzo (2001); e Abbad et al., (2001); Rodrigues (2000); Meneses e Abbad (2003); Lacerda e Abbad (2003); Zerbini (2003); e Freitas (2005). 
À utilização da auto e heteroavaliação vem de encontro às sugestões dos estudiosos sobre a necessidade de comparar percepções dos diferentes agentes envolvidos e esta é uma forma de garantir maior confiabilidade no julgamento sobre o impacto de treinamento. Leitão (1996); Abbad (1999); Sallorenzo (2000); Meneses e Abbad (2003).

Os resultados evidenciaram na percepção dos auto e heteroavaliadores, para o alcance dos objetivos, que houve impacto de treinamento a cerca dos efeitos produzidos pelo treinamento em seus níveis de desempenho, motivação, autoconfiança e abertura a mudança nos processo de trabalho (ABBAD, 1999). Outras afirmações sobre o impacto no trabalho, podem ser verificadas nas definições dos pesquisadores que têm estudado o assunto: Abbad (1999); Meneses (2002); Zerbini (2003); Borges-Adndrade (2004) e Freitas at. al.,(2006).

Os resultados indicaram que os "treinandos" foram mais rigorosos em suas avaliações do que seus "chefes e pares", com a maioria dos resultados para concordância parcial, uma das possíveis razões para o próprio treinando perceber menor impacto podem está no fato de que ele provavelmente conhece melhor o que se espera de seu comportamento após o treinamento. Estudos realizados por Borges-Andrade e Colab (1999); Pantoja e Colab (2001); Mourão (2004); Freitas (2005) e Araújo (2005).

É interessante notar que, de modo geral, as respostas evidenciaram que na percepção dos respondentes houve impacto de desempenho no nível de trabalho. Para Carvalho e Nascimento (1997 apud CAMPUS et. al, 2004) o treinamento só se completa na medida em que a aquisição de conhecimentos e informações possibilitam ao treinando mudanças de comportamento (forma de conduta) O impacto no nível de comportamento no cargo foi verificado por inúmeros pesquisadores entre eles: Paula (1992); Leitão, (1994); Abbad (1999); Abbad, Gama e Borges-Andrade (2000); Sallorenzo (2000); Rodrigues (2000); Mota (2002); Lacerda (2002); Tamayo (2002) Meneses (2002) Carvalho (2003); Zerbini (2003). Essas mudanças foram percebidas pelos "treinandos", "chefes e pares", como mostram as respostas da pesquisa qualitativa sobre contribuições:

- Proporcionou habilidades técnicas e conceituais, melhorou o desempenho das atividades.

- Melhorou as relações interpessoais, a comunicação e a liderança.

- Contribuiu para a eficácia e aprimoramento das atividades de modo geral.

Juntem-se a esses resultados as colocações de Colquit, Lepine e Noe (2000 apud ARAÚJO, 2005) "quando assinalam que a transferência relaciona-se com auto-eficácia e é definida como a percepção do indivíduo quanto á sua capacidade de aprender e aplicar o aprendido em suas atividades de trabalho". Interpretação para este fato pode estar em que a 
eficácia nas tarefas podem estar justamente associadas aos novos conhecimentos e habilidades aprendidos no treinamento que são colocados frequentemente em prática.

$\mathrm{O}$ fato dos resultados terem sido positivos não significa que não existam partes do treinamento que não mereçam ser melhoradas.

A seguir conclusão e considerações finais, sugestões e recomendações. 


\section{CONCLUSÃO E CONSIDERAÇÕES GERAIS}

Esta pesquisa consistiu, fundamentalmente em responder qual o impacto do treinamento no trabalho do servidor para o desempenho de suas atividades e estabeleceu como objetivo identificar o uso dos conteúdos abordados no curso de Formação e Desenvolvimento Gerencial (FDG) em situações de trabalho, de acordo com a percepção dos participantes.

O foco deste estudo foi à identificação e aplicação do aprendido no trabalho, feita através da avaliação de conteúdo de freqüência e importância de uso dos conteúdos e avaliação dos objetivos alcançados pelo curso. A efetividade do treinamento compreende a transferência para o trabalho dos conhecimentos, habilidades e atitudes adquiridas após treinamento; na percepção dos "treinandos" houve transferência de aprendizagem e aplicação em seu trabalho dos conteúdos oferecidos nas disciplinas: "Universidade Instituição"; "Os Sistemas da Universidade"; "Gestão da Universidade"; "Humanização da Universidade" e “Trabalho Final".

Os resultados evidenciaram a repercussão positiva do curso de Formação e Desenvolvimento Gerencial (FDG) no desempenho dos indivíduos. Na comparação entre auto e heteroavaliadores, em relação ao alcance dos objetivos, os resultados indicaram percepção de impacto do treinamento sobre o desempenho nas atividades de trabalho. O melhor impacto é percebido sobre o desempenho nos conteúdos: "O conhecimento adquirido melhorou o desempenho no trabalho" e "Integrou conhecimentos gerais e específicos na execução do trabalho diário“. Se as pessoas melhoraram o seu desempenho (e essa melhoria é percebida não só pelo treinando, mas também por suas chefias e pares), quanto ao alcance dos objetivos precípuos do curso e da organização, acredita-se que houve confirmação de impacto no trabalho.

A pesquisa qualitativa mostrou o resultado da contribuição de T\&D sobre o desempenho das pessoas (produto); evidenciou a transferência, isto è, a aplicação de aprendizagens adquiridas em T\&D na situação de trabalho (processo). Enquanto treinamento este curso atendeu aos seus objetivos, pois contribuiu de acordo com os resultados dos dados de "treinandos", "chefias e pares", para o aprimoramento do aprendizado; aumento da eficiência individual; aumento das habilidades individuais, para melhorar relacionamentos interpessoais; mudanças de comportamentos individuais; e no nível das tarefas e operações: aumento de produtividade, melhoria da qualidade dos serviços. Esse resultado mostra que houve mudança no comportamento do treinamento no trabalho. Infere-se, que os gerentes 
estão preparados, porque houve impacto no nível de trabalho e que a soma desses resultados resulta em retorno sobre o investimento.

O treinamento nas esferas da moderna organização assume hoje, novos contornos e crescente relevância, em função das competências requeridas para um bom nível de produtividade e competitividade. Mostra-se através dos resultados desta pesquisa, sua relevância para a organização, oportuniza-se realimentação ao sistema de treinamento, que poderá aprimorar o curso de Formação e Desenvolvimento Gerencial (FDG) e assim determinar o valor desse treinamento à luz dessas informações.

A partir desses resultados sugere-se: dar continuidade ao curso de Formação e Desenvolvimento Gerencial (FDG) com critérios previamente definidos, procurando aprimorá-lo; melhorar o planejamento, retirar o excesso de conteúdo que resulta em treinamento dispersivo e desnecessário, porque a falta de adequação das teorias à prática organizacional é um fator que merece atenção.

Recomenda-se aprofundamento da pesquisa em função da pouca utilização de alguns conteúdos. Assim como, merecem ser avaliadas nas próximas pesquisas, as condições de suporte psicossocial.

Verifica-se que nem sempre os setores de treinamento nas organizações consideram prioridade fazer avaliações, que confirmem os resultados que foram alcançados após o treinamento. Acredita-se ser essa avaliação de treinamento, nossa maior contribuição. 


\section{REFERÊNCIAS}

ABBAD. G.S. Um modelo integrado de avaliação do impacto do treinamento no trabalho - IMPACT. 1999.262. Tese (Doutorado em Psicologia) - Instituto de Psicologia, Universidade de Brasília, Brasília, 1999.

ABBAD et al. Medidas de suporte em avaliação de TD\&E. In: BORGES-ANDRADE, J.E.; ABBAD, G.S.; MOURÃO, L. e colaboradores. Treinamento, desenvolvimento e educação em organizações e trabalho: fundamentos para a gestão de pessoas. Porto Alegre: Artmed, 2006, cap. 20.

ABBAD, G.S.; BORGES-ANDRADE, J. E. Aprendizagem humana em organizações de trabalho. In: ZANELLI, J. C.; BORGES-ANDRADE, J. E. e BASTOS, A. V. B. (Orgs.) Psicologia, organizações e trabalho no Brasil. Porto Alegre: Artmed, 2004, cap. 7, p. 237257.

ABBAD, G.S.; FREITAS, I. A; PILATI, R. Contexto de trabalho, desempenho competente e necessidades em TD\&E. In: BORGES-ANDRADE, J.E.; ABBAD, G.S.; MOUR ÂO, L. e colaboradores. Treinamento, desenvolvimento e educação em organizações e trabalho: fundamentos para a gestão de pessoas. Porto Alegre: Artmed, 2006. cap.12

ARAÚJO, M. F. Impacto de treinamento e desenvolvimento uma análise integrada quantitativa e qualitativa. Dissertação (Tese de Doutorado) Pós-Graduação em Engenharia de Produção. Universidade Federal de Santa Catarina. 2005.

BARDIN, L.Análise de conteúdo.Edições 70. 2002.

BITENCOURT,C.C.A gestão de competências gerenciais e a contribuição da aprendizagem organizacional. RAE. v. 44,.n..1, jan/mar. P. 58-69, 2004.

BOOG, G. G. Manual de Treinamento e Desenvolvimento - ABTO. GUSTAVO, G.G. (Coord). 3. ed. São Paulo, Person Education do Brasil, 1999.

BORGES ANDRADE, J.E; LIMA, S.M.V. Avaliação de necessidades de treinamento: um método de análise do papel reocupacional. Tecnologia educacional, v.12, n. 54, p. 6-22, 1983.

BORGES-ANDRADE, J.E.; ABBAD, G. S. Treinamento no Brasil: reflexões sobre suas pesquisas. Revista de Administração, USP, p. 112-125, 1996.

BORGES-ANDRADE, J.E.; Desenvolvimento de medidas em avaliação de treinamento. Estudos de Psicologia, Brasília, v.7, 2002.

Avaliação integrada e somativa em TD\&E. In: FREITAS, I. A .COSTA, M. A F. Metodologia da Pesquisa: conceitos e técnicas. Rio de Janeiro: Interciência, 2001.

CAMPOS, K.C.L. et al. Avaliação do Sistema de Treinamento em Empresas Paulistas de Médio e Grande Porte. Universidade São Francisco, Itatiba-SP, Psicologia: Reflexão e Crítica, 2004, v.17, n. 3. p. 435- 446.

CHIAVENTATO, I. Treinamento e desenvolvimento de recursos humanos: como incrementar talentos na empresa. $4^{\text {a }}$. ed. São Paulo: Atlas, 1999.

DE CENZO, D.A; ROBBINS, S.P. Administração de recursos humanos. 6. ed. Rio de Janeiro: LTC, 2001.

DRUCKER, P. F. Peter Drucker e as tendências da administração no século XXI. 1999.

FRANCO, M.L. P. B. Análise de conteúdo. Brasília: Plano, 2003. 
FREITAS, I. A. et al. Medidas de impacto de TD\&E no trabalho e nas organizações. In: BORGES-ANDRADE, J.E.; ABBAD, G.S.; MOURÃO, L. e colaboradores. Treinamento, desenvolvimento e educação em organizações e trabalho: fundamentos para a gestão de pessoas. Porto Alegre: Artmed, 2006. cap. 24.

FREITAS, I. A. Impacto de treinamento nos desempenhos do indivíduo e do grupo de trabalho: suas relações com crenças sobre o sistema de treinamento e suporte à crença sobre o sistema de treinamento e suporte à aprendizagem contínua. Tese (Doutorado em Psicologia.) Instituto de Psicologia, Universidade de Brasília, Brasília, DF, 2005.

FUNDAÇÃO UNIVERSIDADE DE BRASÍLIA. Secretaria de Recursos Humanos. Projeto de criação do curso de formação e desenvolvimento gerencial. 2007.

GASKELL, G. Entrevistas individuais e grupais. In: BAUER, M. W. Pesquisa qualitativa com texto, imagem e som: um manual prático. Petrópolis, RJ: Vozes, 2002. p. 64-88

HANKE, C. Impacto do Treinamento no trabalho: Análise de ações de capacitação de Auditores do Banco do Brasil. 2006. p. 16-17.

KANAANE, R.; ORTIGOSO, S. Manual de treinamento e desenvolvimento do potencial humano. São Paulo; Atlas, 2001.

KIRKPATRICK, D.L. Programas de evolução de treinamento: modelo dos quatro níveis. São Francisco. 1998.

LACERDA, E. R. Impacto do treinamento no trabalho: investigando variáveis motivacionais organizacionais como suas preditoras. RAC. v.7, n.4 out/dez. 2003, p. 77-96.

MAGALHÃES, M.L.; BORGES-ANDRADE, J. Auto e hetero-avaliação no diagnóstico de necessidades de treinamento. Estudos de Psicologia. 2001, v.6, n.1, p. 33-50.

MARRA, J.P. Administração de recursos humanos: do operacional ao estratégico. 3. ed. São Paulo: Futura, 2000.

MENEZES, P.P.M. Auto-eficácia, lócus de controle, suporte à transferência e impacto do treinamento no trabalho. Tese (Mestrado em Psicologia) Instituto de Psicologia.

Universidade de Brasília, Brasília, DF. 2002.

MOURÃO, L. Avaliação de programas públicos de treinamento: um estudo sobre o impacto no trabalho e na geração de emprego. Dissertação (Tese de Doutorado ). Instituto de Psicologia. Universidade de Brasília. 2004.

NÓBREGA-JUNIOR, F. O impacto de cursos de capacitação no fator liderança da pesquisa de clima e da avaliação de desempenho de uma instituição financeira.

Dissertação (Mestrado em Administração). Departamento de Administração. Universidade de Brasília, Brasília, DF, 2003.

NEVES JR, L.T. Aplicação dos conceitos de educação a distância no treinamento. Estudo de caso em uma rede de farmácias. (Dissertação de Mestrado) UFSC. 2002.

ODELIUS, C.C. Administração de pessoas no limiar do século XXI: uma análise retrospectiva algumas recomendações a respeito da atuação em recrutamento, seleção, treinamento e desenvolvimento. 1999.

PANTOJA, M. J. et al. Valores, suporte psicossocial e impacto do treinamento no trabalho. Estudos de Psicologia, Brasília, v. 10. n.2, set., 2005. 
PANTOJA, M.J, PORTO. J.B.; MOURÃO, BORGE, E.J., Valores, suporte psicossocial e impacto do treinamento no trabalho. Estudos de psicologia (Natal) v.10, Natal. maio/ago, 2005.

PEREIRA, C. M. Contribuições de um Programa de TD\&E para a implementação de estratégias corporativas e para o desempenho organizacional. Projeto. Instituto de Psicologia, Universidade de Brasília, jul. 2007. p. 2- 4.

PILATI, R.; ABBAD.G. Impacto do treinamento no trabalho: teoria e pesquisa, v. 21 , n. 1 p. 43-51, 2005.

PILATI, R.; BORGES-ANDRADE, J. Estudo Empírico das Antecedentes de medidas de Impacto do Treinamento do Trabalho. Psicologia: Teoria e pesquisa. jan./abr. 2004, v. 20 n.1, p. 31-38.

PILATI, R. Historia e importância de TD\&E. In: BORGES-ANDRADE, J.E.; ABBAD, G.S.; MOURÃO, L. e colaboradores. Treinamento, desenvolvimento e educação em organizações e trabalho: fundamentos para a gestão de pessoas. Porto Alegre: Artmed, 2006. cap. 8.

.Estratégias para aplicação no trabalho do aprendido em treinamento: proposição conceitual e desenvolvimento de uma medida. Psicologia: Reflexão e Crítica, Brasília, abr. 2005, v. 18. n.2, p. 207-214.

Construção de medidas e delineamentos em avaliação de TD\&E. In: BORGESANDRADE, J.E.; ABBAD, G.S.; MOURÃO, L. e colaboradores. Treinamento, desenvolvimento e educação em organizações e trabalho: fundamentos para a gestão de pessoas. Porto Alegre: Artmed, 2006. cap.18.

SALLORENZO, L. H. Avaliação de impacto de treinamento no trabalho: analisando e comparando modelos de predição. Dissertação (Mestrado em Psicologia) Instituto de Psicologia, Universidade de Brasília, Brasília, 2000.

SILVA, A. A. R; MORAES, L. F. R. Avaliação de resultados de treinamentos de treinamento no setor público: um estudo de caso no BDMG. In: XXVIII Anais do ENANPAD 2004. Curitiba, 2004.

SILVA. M.E. Relações entre impacto do treinamento e estratégia empresarial: o caso da Eletronorte. Dissertação (Departamento de Administração), 2002.

SPECTOR, P. E. Psicologia nas Organizacões. 2a . ed., São Paulo: Saraiva, 2006.

VARGAS, M. R. M.; ABBAD, G.S. Bases conceituais em treinamento, desenvolvimento e educação - TD\&E. In: BORGES-ANDRADE, J.E.; ABBAD, G.S.; MOURÃO, L. e colaboradores. Treinamento, desenvolvimento e educação em organizações e trabalho: fundamentos para a gestão de pessoas. Porto Alegre: Artmed, 2006. cap.7.

VARGAS, M. R.M. Treinamento e desenvolvimento: reflexões sobre seus métodos. Revista de Administração, São Paulo v.31, n.2, p.126-136, abr./jun., 1996.

VERGARA, S.C. Projetos e Relatórios de Pesquisa em Administração.5. ed. São Paulo: Atlas, 2004.

VERGARA, S.C. Começando a definir a metodologia. In: Projetos e relatórios de pesquisa em Administração. 3. ed. São Paulo: Atlas, 2000. cap. 4, p. 4-53.

ZERBINI. T. Estratégias de aprendizagem, reações aos procedimentos de um curso via Internet, reações ao tutor e impacto do treinamento no trabalho. Tese (Mestrado em Psicologia) Instituto de Psicologia, Universidade de Brasília, Brasília, DF, 2003. 
ZERBINI, T.; ABBAD, G. Impacto de Treinamento no Trabalho via Internet. RAE eletrônica. v.4, n.2, art. 16, jul/dez., 2005. 
APÊNDICE

INSTRUMENTO PARA COLETA DE DADOS 
APÊNDICE - Corpo do e-mail que solicita marcar encontro

Ao treinando

Convido-o(a) a participar de uma pesquisa que fará parte de minha monografia de pósgraduação em Gestão Universitária, sobre o tema Avaliação de Impacto em profundidade: Curso de Formação e Desenvolvimento Gerencial. O objetivo deste questionário é coletar dados sobre o impacto das disciplinas do curso de Formação e Desenvolvimento Gerencial oferecido aos gestores da Universidade de Brasília, na 4ª Turma, que teve início em março de 2007.

Todos os dados serão tabulados e tratados de forma confidencial.

Conheço a dificuldade de cada gerente e servidor em disponibilizar tempo para atividades dessa natureza, por isso, agradeço a sua colaboração e ressalto que o questionário é simples.

Conto com sua prestimosa ajuda para marcar o melhor horário e dia, com a maior brevidade possível, para que possa ser aplicado em seu setor de trabalho, se possível envie a localização de onde trabalha.

Mais uma vez agradeço sua atenção e empenho. Aguardo a sua resposta até 108. 